\title{
Autophagy in Cisplatin Nephrotoxicity during Cancer Therapy
}

\author{
Xiaoru Hu ${ }^{1,2,3}$, Zhengwei Ma 2,3, Lu Wen ${ }^{1,2,3}$, Siyao Li 1,2,3 (D) and Zheng Dong ${ }^{1,2,3, *(\mathbb{D})}$ \\ 1 Hunan Key Laboratory of Kidney Disease and Blood Purification, Department of Nephrology, The Second \\ Xiangya Hospital of Central South University, Changsha 410011, China; 188201029@csu.edu.cn (X.H.); \\ 188201019@csu.edu.cn (L.W.); lisiyao0716@csu.edu.cn (S.L.) \\ 2 Department of Cellular Biology and Anatomy, Medical College of Georgia, Augusta University, \\ Augusta, GA 30912, USA; ZMA@augusta.edu \\ 3 Charlie Norwood VA Medical Center, Augusta, GA 30912, USA \\ * Correspondence: zdong@augusta.edu; Tel.: +1-706-721-2825; Fax: +1-706-721-6120
}

check for updates

Citation: Hu, X.; Ma, Z.; Wen, L.; Li, S.; Dong, Z. Autophagy in Cisplatin Nephrotoxicity during Cancer Therapy. Cancers 2021, 13, 5618. https://doi.org/10.3390/ cancers 13225618

Academic Editor: Vanessa SotoCerrato

Received: 13 September 2021

Accepted: 4 November 2021

Published: 10 November 2021

Publisher's Note: MDPI stays neutral with regard to jurisdictional claims in published maps and institutional affiliations.

Copyright: (c) 2021 by the authors. Licensee MDPI, Basel, Switzerland. This article is an open access article distributed under the terms and conditions of the Creative Commons Attribution (CC BY) license (https:/ / creativecommons.org/licenses/by/ $4.0 /)$.
Simple Summary: Cisplatin is a broadly used chemotherapy drug, but its use and efficacy are limited by its nephrotoxicity. Autophagy protects against kidney injury during cisplatin exposure but may reduce the efficacy of chemotherapy by protecting cancer cells. In this review, we describe the role and regulation of autophagy in cisplatin-induced nephrotoxicity and discuss the therapeutic advances and challenges of targeting autophagy in chemotherapy.

\begin{abstract}
Cisplatin is a widely used chemotherapeutic agent but its clinical use is often limited by nephrotoxicity. Autophagy is a lysosomal degradation pathway that removes protein aggregates and damaged or dysfunctional cellular organelles for maintaining cell homeostasis. Upon cisplatin exposure, autophagy is rapidly activated in renal tubule cells to protect against acute cisplatin nephrotoxicity. Mechanistically, the protective effect is mainly related to the clearance of damaged mitochondria via mitophagy. The role and regulation of autophagy in chronic kidney problems after cisplatin treatment are currently unclear, despite the significance of research in this area. In cancers, autophagy may prevent tumorigenesis, but autophagy may reduce the efficacy of chemotherapy by protecting cancer cells. Future research should focus on developing drugs that enhance the anti-tumor effects of cisplatin while protecting kidneys during cisplatin chemotherapy.
\end{abstract}

Keywords: cisplatin; autophagy; acute kidney injury; chronic kidney disease; nephrotoxicity; cancer therapy

\section{Introduction}

Cisplatin is a potent chemotherapy drug used for the treatment of various types of tumors [1], but it has remarkable side effects or toxicity in normal tissues [2]. The kidney is highly vulnerable to cisplatin toxicity due to the accumulation of cisplatin in renal tubule cells [3]. Acute kidney injury occurs in 20-30\% of patients and manifests as kidney cell death, tissue damage, rapid loss of renal function or renal failure, and even death [4]. Following cisplatin chemotherapy, a significant portion of cancer patients develop chronic kidney problems [5]. Therefore, it is vital to explore the mechanism of the nephrotoxicity of cisplatin and identify preventive or protective measures.

Autophagy is a lysosomal degradation pathway that clears dysfunctional or obsolete cytoplasmic components [6,7]. In the kidney, the basal level of autophagy plays a role in maintaining renal cell homeostasis and function under normal physiological conditions. Autophagy is induced in response to cellular stress when the kidney is diseased or exposed to insults or toxins, such as cisplatin. Autophagy is generally considered pivotal in promoting cell survival and protecting against acute cisplatin nephrotoxicity [8-11]. Autophagy also participates in the regulation of maladaptive kidney repair and renal fibrosis after acute kidney injury and during the progression of chronic kidney disease [12-17]. However, 
little is known about the role and regulation of autophagy in the development of chronic kidney problems after cisplatin exposure.

In cancers, the role of autophagy is Janus-faced. On the one hand, it may limit or prevent tumorigenesis, but, on the other hand, autophagy may reduce the efficacy of cancer therapy by promoting cancer cell survival [18]. Autophagy induction by cisplatin is associated with the development of cisplatin resistance in many types of cancer cells, including bladder cancer, esophageal cancer [19], lung cancer [20], ovarian cancer [21], and bone cancer [22]. Moreover, the association between the loss of autophagy genes and the decrease in other tumors' sensitivity to chemotherapy drugs further highlights the significance of autophagy in cancer suppression in some tumors [23]. Therefore, autophagy upregulation can protect the kidneys against acute cisplatin injury, but its effect on cancers is context-dependent. When targeting autophagy as a strategy for kidney protection, the effect on tumors must be considered.

This review analyzes the current research about autophagy in cisplatin-induced acute and chronic kidney diseases from its occurrence to function and regulation. We further discuss the therapeutic potential and the challenges of targeting autophagy for kidney protection in cisplatin-mediated chemotherapy.

\section{Cisplatin Nephrotoxicity}

Cisplatin is efficacious for solid tumor treatment, either alone or in combination with other therapies, but it also causes toxicity in multiple organs and tissues, especially in the kidney $[1,24]$. Approximately $20-30 \%$ of patients who receive cisplatin develop acute kidney injury (AKI), which is characterized by rapid loss of renal function, the accumulation of end products of nitrogen metabolism, and the disturbance of water and electrolytes [25]. The long-term effects of cisplatin on the kidney are not entirely understood. Brillet et al. [26] and Latcha et al. [5] reported that cisplatin might lead to a subclinical but persistent low glomerular filtration rate. Therefore, a thorough understanding of AKI and CKD induced by cisplatin is necessary for clinical treatment.

\subsection{Cisplatin-Induced Acute Kidney Injury}

Cisplatin nephrotoxicity is a multifactorial process including various pathophysiological events, such as microvascular disorders, tubular injury, tubular cell death, and inflammatory response. Among them, tubular cell injury and death is a critical pathological feature [27-29]. In experimental models of AKI, the proximal tubule, especially the S3 segment, is highly sensitive and most vulnerable to damage [30,31]. The renal tubule damages caused by cisplatin are often manifested as tubule dilation, cast formation, and tubular cell apoptosis and necrosis [32,33].

Many studies have focused on the cellular and molecular mechanisms of tubular damage, especially proximal tubular injury. Renal tubular cells mainly uptake cisplatin through organic cation transporters 2 (OCT2) [34] and copper transporter 1 (CTR1) [35]. After entry into the cell, cisplatin may undergo a series of bio-activation processes to generate various toxic metabolites, which are catalyzed by $\gamma$-glutamyl transpeptidase (GGT) and cysteine-S-conjugate $\beta$-lyase [36]. Then, it may bind to DNA, leading to interand intrastrand cross-links [37], causing DNA damage and DNA-damage response [38,39], resulting in cell cycle arrest and cell death [40]. Multiple signaling pathways are activated upon cisplatin exposure, such as mitogen-activated protein kinases (MAPKs) [41] and the p53-DNA damage response pathway [42,43], leading to apoptosis, necroptosis [44], and ferroptosis [45]. Cisplatin also evokes oxidative stress [46], ER stress [47], mitochondrial dysfunction [48].

\subsection{Cisplatin-Induced Chronic Effects in the Kidney}

Currently, a common regimen of cisplatin treatment is weekly administration of relatively low doses of cisplatin for several cycles. While this regimen reduces the side effects of cisplatin, a significant portion of patients still develop acute kidney injury, and 
some progress into chronic kidney disease. Repeated low-dose cisplatin (RLDC) treatment models were established to study chronic kidney problems after cisplatin treatment.

In 2011, we reported the first RLDC model, in which tumor-bearing mice were treated weekly with $10 \mathrm{mg} / \mathrm{kg}$ cisplatin for 4 weeks to study the effects in tumors and kidneys [49]. Subsequently, several mouse models of RLDC treatment were established with different animal ages, animal strains, the dosage of cisplatin, and observation time [50-55]. The aging FVB/n mice were more resistant to $7 \mathrm{mg} / \mathrm{kg}$ cisplatin weekly for 4 weeks than young mice, which showed less inflammation and fibrosis [56]. Moreover, C57BL/6 mice require a higher dose of cisplatin to induce renal fibrosis than FVB/n mice [57]. In addition to age and strain, dosing regimens influence fibrotic changes; $10 \mathrm{mg} / \mathrm{kg}$ cisplatin once a week for three times and $7 \mathrm{mg} / \mathrm{kg}$ once a week for 4 weeks induced moderate renal interstitial fibrosis in male FVB/N mice [55,58]. C57BL/ 6 mice treated with $8 \mathrm{mg} / \mathrm{kg}$ cisplatin weekly for 4 weeks [51] and FVB/n mice treated with $7 \mathrm{mg} / \mathrm{kg}$ cisplatin weekly for 4 weeks [55,59] both showed a time-dependent increase in renal fibrosis.

Although renal fibrosis is a hallmark of progressive kidney disease, there is evidence that fibrosis may not be critical to CKD development after RLDC treatment. Landau et al. [50] emphasized that fibrosis may not play a prominent role in CKD progression in C57BL/6 mice after two doses of $15 \mathrm{mg} / \mathrm{kg}$ cisplatin with an interval of two weeks. Consistently, this model only had a minor increase in renal fibrosis, despite a significant loss of renal function [53], as did the mice receiving three weekly injections of $9 \mathrm{mg} / \mathrm{kg}$ cisplatin [52]. Thus, in these relatively severe injury models induced by relatively high doses of cisplatin, unresolved tubular damage and capillary rarefaction, rather fibrosis, are closely associated with CKD progression [50,58].

In addition to renal fibrosis, there are still other pathogenesis studied in this model. Macrophage activation [51,60] with the secretion of inflammatory factors $[51,54,58,59]$, such as Tnfa, Csf1, Mcp1, and Cxcl1, occurred in kidneys after RLDC treatment as well. Interestingly, several studies $[50,51,53]$ showed atubular glomeruli in cisplatin-induced $\mathrm{CKD}$, associated with renal function decline. Growing evidence suggests that tubular injury affects glomerular pathophysiology, potentially due to impaired tubuloglomerular crosstalk, peritubular inflammation, or PTC rarefaction. Thus, the glomerular injury may occur after tubular injury [58]. Finally, antioxidant [60] and anti-senescence compounds [61,62] partially delayed CKD progression after RLDC treatment, suggesting the involvement of reactive oxygen species and cell senescence in the pathogenesis.

Collectively, RLDC-induced pathological changes include tubular atrophy, tubulointerstitial fibrosis, chronic inflammatory infiltration, capillary dysfunction, tubular cell death, notable atubular glomeruli, and glomerulosclerosis in some circumstances [59], leading to kidney atrophy and a decline in kidney function. The occurrence of these pathological features may depend on the experimental models, especially the severity of initial kidney injury.

\section{Autophagy in Cisplatin-Induced AKI}

\subsection{Basics of Autophagy}

\subsubsection{Three Forms of Autophagy}

Autophagy is a highly conserved cellular process of catabolism that degrades cytoplasmic components. Depending on the type of cargo and delivery method, autophagy can be classified as macroautophagy, microautophagy, and chaperone mediated autophagy. Macroautophagy (hereafter termed autophagy) is a "bulk" degradation of large cytoplasmic materials that are engulfed by autophagosomes, which fuse with lysosomes for degradation [63]. Microautophagy involves the direct sequestration of relatively small cytoplasmic substances into lysosomes through invagination of the lysosomal membrane [64]. Chaperone mediated autophagy (CMA) is a highly selective pathway in which chaperoneHSC70 recognizes the KFERQ motif-containing proteins and targets the substrate to the lysosome surface. Then, this substrate protein-chaperone complex binds to lysosome- 
associated membrane protein type 2A (LAMP-2A) to access the lysosome for degradation [65] (Figure 1).

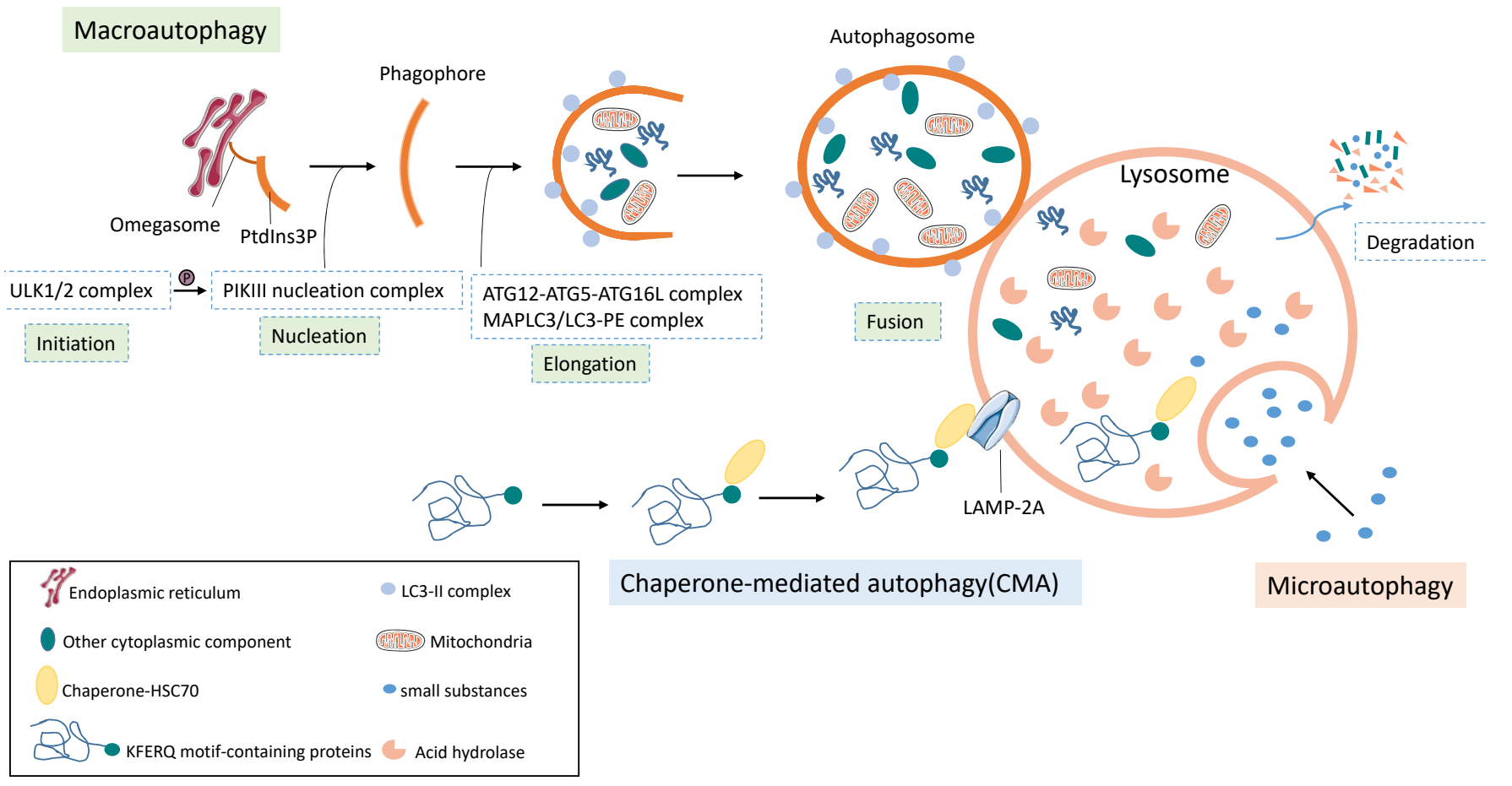

Figure 1. The process of autophagy. According to the type of cargo and delivery method, autophagy can be classified as macroautophagy, microautophagy, and chaperone-mediated autophagy (CMA). Macroautophagy is a process that autophagosome fuses with a lysosome to form an autolysosome, which mainly degrades dysfunctional or obsolete cytoplasmic components. Several complexes composed of autophagy-related proteins (ATG) act synergistically with membrane transport components resulting in the formation of autophagosome. CMA is a highly selective pathway, KFERQ motif-containing proteins recognized by Chaperone-HSC70 binds to LAMP-2A located in lysosome to be degraded. Small cytoplasmic substances are engulfed directly by the lysosome, called microautophagy.

\subsubsection{Overview of Autophagy}

Autophagy is a dynamic and complex process involving a series of cellular events. The core events are the formation of autophagosomes and autolysosomes. Several complexes composed of autophagy-related proteins (ATG) act synergistically with membrane transport components resulting in the formation of the autophagosome. The entire process of autophagy includes five distinct stages: initiation, vesicle nucleation, vesicle elongation, vesicle fusion, and cargo degradation. Initially, one cell compartment consisting of lipid bilayer membranes enriched for phosphatidylinositol 3-phosphate (PtdIns3P), called omegasome, forms on the endoplasmic reticulum (ER) membrane [66]. Meanwhile, the ULK1/2 complex senses the stress signal to activate the PIKIII nucleation complex by phosphorylating its component Beclin-1 [67], thus promoting vesicle nucleation and elongation to cause phagophores (also called "isolation membranes") formation on the site of the omegasome. Then, two ubiquitin (Ub)-like conjugation systems, the ATG12-ATG5-ATG16L complex and the microtubule-associated protein light chain 3-phosphatidyl ethanolamine (MAPLC3/LC3-PE), help the phagophore expand to form autophagosome [68]. Finally, the autophagosome fuses with a lysosome to form an autolysosome, which degrades the autophagosome inner membrane and the engulfed cytoplasmic substrates by acidic lysosomal hydrolases [7] (Figure 1).

\subsection{Induction of Autophagy in Cisplatin AKI}

In 2008, two independent studies [69,70] reported the first evidence of autophagy activation in cisplatin-induced acute nephrotoxicity. While Yang et al. [69] showed au- 
tophagy activation during cisplatin treatment of LLC-PK1 cells, we [70] demonstrated autophagy induction during cisplatin treatment of rat proximal tubular cells (RPTCs) and acute nephrotoxicity in mice induced by a single dose of $30 \mathrm{mg} / \mathrm{kg}$ cisplatin. Notably, both studies indicated that blockade of autophagy enhanced apoptosis during cisplatin treatment of renal tubular cells, suggesting a protective role of autophagy.

Cisplatin causes multiple forms of cellular stress, such as DNA damage, mitochondrial damage, ROS, and ER stress, which may play a role in autophagy activation in cisplatininduced AKI.

\subsubsection{Oxidative Stress and Autophagy}

Oxidative stress, with a significant role in the pathogenesis of cisplatin nephrotoxicity [71], may regulate autophagy in cisplatin AKI. This is suggested by the effects of two regulators of ROS production, heme oxygenase-1 (HO-1) and NAD $(\mathrm{P}) \mathrm{H}$ : quinone oxidoreductase 1 (NQO1). HO-1, a microsomal antioxidase that catalyzes the transformation of heme to biliverdin releasing iron and carbon monoxide, was reported to inhibit autophagy in cisplatin AKI [72]. In particular, HO-1-deficient mice had significantly more autophagosomes, even under control conditions. In addition, overexpression of HO-1 in cells significantly lowered the levels of reactive oxygen species, led to a delay in autophagy progression, and decreased cell death after cisplatin injury. Thus, HO-1 may suppress autophagy via its anti-oxidant activity. NQO1 is another cytoprotective gene with antioxidant function. Kim et al. [73] reported that cisplatin-induced ROS production and NQO1 expression in cisplatin AKI, together with elevated tubular injury and death. Notably, NQO1 knockdown cells and NQO1-KO mice showed more ROS production and increased expression of autophagy-associated protein than their wild-type counterparts. One possibility is that increased ROS production in NQO1-deficient cells and mice led to autophagy activation for protection and adaptation to the stress. Together, these studies imply that oxidative stress may promote autophagy induction in cisplatin AKI.

\subsubsection{Endoplasmic Reticulum Stress and Autophagy}

ER stress is induced along with autophagy after both cisplatin exposure [74,75] and ischemia-reperfusion (IR) injury [76]. Whether autophagy induction is related to ER stress was confirmed by pharmacological approaches. For example, inhibitors of ER stress suppressed cyclosporine-induced autophagy [75] and activators of ER stress notably increased autophagy in renal proximal tubular cells [77]. Our recent study has further demonstrated a reciprocal regulation between ER stress and autophagy in renal tubular cells. Specifically, ER stress induces autophagy leading to fibrotic changes in renal tubular cells, whereas autophagy, upon activation, reduces ER stress in these cells providing a negative feedback mechanism. ER stress might affect the induction of autophagy via regulating calcium release, $\mathrm{REDD} 1 / \mathrm{mTOR}$, and AKT/mTOR pathways. Moreover, the autophagy machinery components are tightly regulated by unfolded protein response (UPR) [78]. Gozuacik et al. [79] showed that death-associated protein kinase1 (DAPK1) was induced by ER stress and regulated autophagy via the phosphorylation of Beclin 1, and autophagy was inhibited in Dapk-null cells in tunicamycin-induced kidney injury. Conceivably, moderate ER stress activates cytoprotective mechanisms such as UPR and autophagy, whereas severe ER stress leads to irreversible cell damage and cell death. Delineating the molecular basis of this shift may lead to new strategies for reducing nephrotoxicity in cisplatin chemotherapy.

\subsubsection{Mitochondrial Damage and Mitophagy}

One main event of renal tubular injury is mitochondrial damage, manifested by structural disruption and functionally by decreased cellular respiration and ATP production $[33,80]$. Usually, mammalian cells have multiple mechanisms for quality control, including mitochondrial biogenesis, dynamics, and mitophagy; however, these mechanisms are disrupted during cell stress or injury resulting in mitochondrial damage [81]. 
Mitophagy removes obsolete or damaged mitochondria to maintain mitochondrial and cellular homeostasis [8,82] (Figure 2).

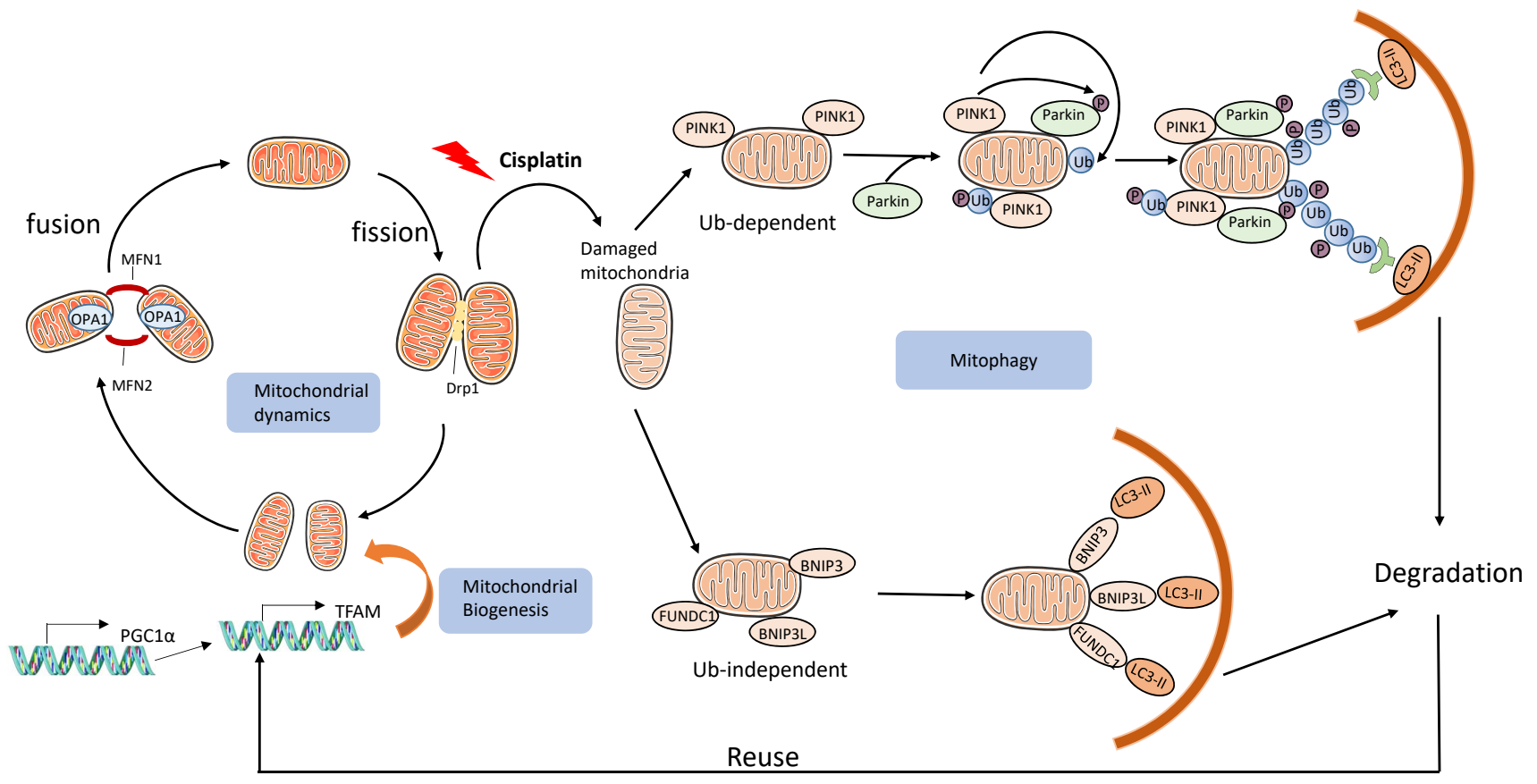

Figure 2. Mitochondrial quality control in cisplatin injury. Mitochondria biogenesis, dynamics, and mitophagy are important mechanisms of mitochondrial quality control. PGC- $1 \alpha$ and TFAM are two important transcription factors for mitochondrial biogenesis. The life cycle of mitochondria begins with the growth and division, and ends with the degradation via mitophagy. In cisplatin nephrotoxicity, mitochondria are damaged and then eliminated by mitophagy.

Mitochondria are dynamic organelles that sustain their shape or morphology via two opposing processes, fission mediated by Drp1 and fusion regulated by mitofusin 1 (MFN1), MFN2, and OPA1 [83]. Mitophagy is a form of selective autophagy whereby dysfunctional mitochondria are degraded via autophagy. Mitochondrial dynamics and mitophagy are intimately related to each other. In 2009, our group reported that mitochondrial fragmentation occurred in kidney injury induced by renal ischemia-reperfusion and cisplatin, which was ameliorated by a pharmacological inhibitor of Drp1 [83]. It is also verified by one study using intravital multiphoton microscopy in live animals [84]. Of interest, it is observed that Drp-1-mediated mitochondrial fission also facilitated mitophagy during cisplatin treatment of renal tubular cells [85]. Although it is unclear whether mitochondrial fission can directly trigger mitophagy, fission-associated ROS overproduction and related signals may at least work together to induce mitophagy [86].

Mitochondrial biogenesis and mitophagy coordinate with each other to maintain homeostasis [87]. The mitochondrial life cycle starts with the growth and division of pre-existing organelles (biogenesis) and ends with the degradation of impaired or surplus organelles by mitophagy (turnover). Two crucial transcription factors are responsible for mitochondrial biogenesis, transcription factor A for mitochondria (TFAM) and the peroxisome proliferator-activated receptor-gamma coactivator 1-alpha (PGC1 $\alpha$ ). Ablation of PGC1 $\alpha$ from renal tubule cells suppressed kidney recovery from septic AKI [88], and PGC1 $\alpha$ is also pivotal for kidney recovery from ischemic injury by regulating nicotinamide adenine dinucleotide (NAD) biosynthesis [89]. Of interest, decreased TFAM protein level and activity of PGC1 $\alpha$ and increased mitophagy were reported cisplatin-treated LLC-PK1 cells, which were prevented by antioxidant $\alpha \mathrm{M}$ [90]. One study explored the relationship between PGC1 $\alpha$ and mitophagy. It showed that PGC1 $\alpha$ could prevent mitophagy impairment in the late kidney injury phase, which accelerates mitochondrial turnover by inducing TFEB to protect against cisplatin AKI [91]. 
Collectively, PGC1 $\alpha$ may be a key regulator of mitochondrial biogenesis and mitophagy, and PGC1 $\alpha$ is a promising target for reducing cisplatin nephrotoxicity in cancer therapy. These findings reveal the role of mitochondrial biogenesis and mitophagy after kidney injury.

\subsection{Roles of Autophagy in Cisplatin Nephrotoxicity and Underlying Mechanisms}

\subsubsection{Protective Role of Autophagy in Acute Cisplatin Nephrotoxicity}

Both pharmacological inhibitors and activators of autophagy were used to explore the role of autophagy in cisplatin nephrotoxicity. 3-MA inhibits autophagosome formation from the beginning, leading to decreased formation of LC3II. Bafilomycin prevents the fusion of autophagosome with lysosome, reducing the degradation of LC3II, while CQ blocks the autophagy flux and impairs cargo clearance [92,93]. Although the mechanisms are different, these autophagy inhibitors increase kidney tubular cell death during cisplatin treatment $[69,70]$. In contrast, activation of autophagy by rapamycin, one mTOR inhibitor, attenuated tubular injury and protected against cisplatin-induced AKI in mice $[70,93,94]$. Several natural compounds, such as neferine, emodin, ginsenoside Rb3, and oridonin, were also reported to protect against cisplatin-induced kidney injury through activating autophagy [95-99].

Besides pharmacological approaches, the protective role of autophagy in kidney injury was demonstrated by using conditional autophagy gene knockout mouse models $[92,100,101]$. Specifically, kidney tubule-specific knockout of Atg7 [92] or Atg5 [100,101] worsened AKI induced by cisplatin or renal ischemia-reperfusion, as shown by more severe tubular injury and loss of renal function. Consistently, knockdown of Beclin1 blocked autophagy and increased apoptosis during cisplatin treatment of renal tubular cells $[69,70,102]$. Taken together, these studies indicate that autophagy is an intrinsic protective mechanism in kidney tubular cells that are activated rapidly in response to acute cisplatin nephrotoxicity for renal protection (Table 1). Other autophagy-related gene deletion models in kidneys should also be studied in the future.

Table 1. Effects of ablation of autophagy genes on cisplatin-induced AKI.

\begin{tabular}{|c|c|c|c|c|c|}
\hline Variation & Method & Target & Effect & $\begin{array}{l}\text { Underlying } \\
\text { Mechanisms }\end{array}$ & Reference \\
\hline \multirow{4}{*}{ Autophagy } & $\operatorname{Atg} 5 \mathrm{KO}$ & $\begin{array}{l}\text { Mouse proximal } \\
\text { tubule }\end{array}$ & More sensitive & $\begin{array}{l}\text { 1. More damaged } \\
\text { mitochondria and } \\
\text { abnormal protein } \\
\text { aggregates accumulation } \\
\text { 2. More DNA damage and } \\
\text { p53 activation }\end{array}$ & [101] \\
\hline & Atg7 KO & $\begin{array}{l}\text { Mouse proximal } \\
\text { tubule }\end{array}$ & More sensitive & $\begin{array}{l}\text { More activation of p53 and } \\
\text { c-Jun } \mathrm{N} \text { terminal kinase }\end{array}$ & [92] \\
\hline & Beclin1 shRNA & NRK-52E cells & Prevent apoptosis & Suppressed apoptosis & [102] \\
\hline & Beclin1 siRNA & RPTCs & $\begin{array}{l}\text { Aggregated } \\
\text { apoptosis and cell } \\
\text { death }\end{array}$ & $\begin{array}{l}\text { Sensitized cells to } \\
\text { cisplatin-induced } \\
\text { apoptosis }\end{array}$ & {$[69,70]$} \\
\hline \multirow{3}{*}{ Mitophagy } & Pink1/parkin $\mathrm{KO}$ & Mouse global & More sensitive & $\begin{array}{l}\text { Promoted Drp1-mediated } \\
\text { mitochondrial fission }\end{array}$ & [94] \\
\hline & $\operatorname{Pink1} \mathrm{KO}$ & Rat global & $\begin{array}{c}\text { Attenuated } \\
\text { cisplatin-induced } \\
\text { acute kidney injury }\end{array}$ & $\begin{array}{l}\text { Promoted Drp1-mediated } \\
\text { mitochondrial fission }\end{array}$ & [103] \\
\hline & $\begin{array}{l}\text { Pink1/parkin } \\
\text { knockdown }\end{array}$ & HK2 cells & More cell injury & $\begin{array}{c}\text { Accelerated } \\
\text { cisplatin-induced } \\
\text { mitochondrial dysfunction }\end{array}$ & [104] \\
\hline
\end{tabular}

NRK-52E line, normal rat kidney epithelial cell line; HK-2, human kidney proximal tubule epithelial cell line; Drp1, dynamin-related protein 1; RPTCs, rat kidney proximal tubule epithelial cell line; Atg5, Autophagy related 5 gene; and Atg7, Autophagy related 7 gene. 


\subsubsection{Mechanisms of the Renoprotective Effect of Autophagy}

Autophagy exerts its function by clearing protein aggregates and damaged organelles for reuse or recycling to maintain cellular homeostasis. The loss of this clearing function results in more damaged mitochondria and accumulation of abnormal protein aggregates, as shown in cisplatin-treated proximal tubule Atg7 [92] or Atg5 [101] knock-out mice. The Atg7-knockout mice also showed more DNA damage and p53 activation than wildtype littermates, suggesting that autophagy dysfunction further exacerbates kidney injury signaling.

While autophagy may protect cells via multiple mechanisms, increasing evidence suggests that mitophagy is a critical defense mechanism in AKI. There are two major pathways of mitophagy: the ubiquitin-dependent pathway and the ubiquitin-independent pathway. The ubiquitin-dependent pathway is also called the PINK1/Parkin pathway, where cell stress-associated loss of mitochondrial membrane potential induces the accumulation of PINK1 on the mitochondrial outer membrane (OMM) where it phosphorylates and recruits Parkin, an E3 ligase, leading to the ubiquitination of OMM proteins. The ubiquitinated mitochondria are then recognized by a series of autophagy receptors with Ub-binding domain and LC3-binding regions, leading to encapsulation by autophagosomes and final degradation in autolysosomes (Figure 2). Initially, it is observed that knockdown of Pink1 or Parkin led to decreased mitophagy and more cell death in cisplatin-treated HK2 cells, which was opposite in overexpression cells [104]. Then, our group [94] demonstrated that Pink1 or Parkin-knockout mice suffered more severe AKI following cisplatin treatment, further supporting a protective role of Pink1/Parkin-mediated mitophagy in cisplatin nephrotoxicity. The ubiquitin-independent pathway involves specific mitophagy receptors, such as BNIP3, BNIP3L, and FUNDC1, which can bind to LC3-II and link damaged mitochondria directly to autophagosomes (Figure 2). In AKI models, BNIP3 is induced in renal tubular cells during ischemic kidney injury and cisplatin nephrotoxicity, and BNIP3 deficiency exacerbated AKI, indicating a protective role of BNIP3-mediated mitophagy in AKI [105-107]. In line with this, panax notoginseng saponins, a Chinese herb medicine, protected against cisplatin-induced kidney apoptosis through HIF-1 $\alpha$ /BNIP3/BCEN-1 pathway [108]. Mitophagy may be induced as an adaptive response rather than a toxic response in the early phase of kidney injury; however, it might be impaired in the late stage, and this impairment could be prevented by $\operatorname{PGC} 1 \alpha$, which accelerates mitochondrial turnover by inducing TFEB to protect against cisplatin AKI [91]. These findings suggest that autophagy protect against cisplatin-induced AKI, and this protective effect is mainly related to the clearance of damaged mitochondria via mitophagy.

\subsection{Regulation of Autophagy in Cisplatin AKI \\ 3.4.1. Energy Signaling Pathway}

It is well recognized that nutrient or energy deprivation is a core reason for the induction of autophagy, which is mainly mediated by mTOR, AMPK, and nicotinamide adenine dinucleotide (NAD+) metabolism.

mTORC1 suppresses autophagy by phosphorylating ULK1 and ATG13 to inhibit the ULK1-ULK2 complex formation and autophagy initiation. Several notable autophagy regulators may work by modulating mTOR complex 1 (mTORC1). AMPK may phosphorylate ULK1 to induce autophagy directly or phosphorylate mTORC1 to induce autophagy indirectly. Growth factors regulate mTORC1 activity mainly by activating two classical pathways of mTORC1, PI3K/AKT/mTORC1, and Ras/Raf/MEK/ERK/mTORC1 signaling pathways [109]. In cisplatin AKI, several factors may regulate autophagy through mTORC1. For example, p53 may activate autophagy through the inhibition of mTORC1 by AMPK [110] or miR-199a-3p [111], while activation of protein kinase C $\delta$ (PKC $\delta$ ) in cisplatin AKI inhibits autophagy through the AKT/mTORC1/ULK1 pathway [112]. Cisplatininduced NQO1 may inhibit autophagy through activation of the AMPK/TSC2/ mTORC1 signaling pathway [73]. In addition, histone deacetylase (HDAC) inhibitors were shown to protect against cisplatin-induced kidney tubular cell injury [113]. More recent work showed 
that HDAC inhibitors may protect kidney tubular cells by enhancing autophagy at least partially by suppressing mTORC1 [114]. Well-known inhibitors of mTORC1, rapamycin, and everolimus both affect the cisplatin kidney injury and repair. Together, these studies indicate a role of $\mathrm{mTORC} 1$ and related signaling in the regulation of autophagy in cisplatin nephrotoxicity.

Importantly, NAD+ metabolism is critical in regulating autophagy, especially in energy deprivation. NAD+ biosynthesis can promote kidney recovery from ischemic injury in mice [89] and impaired NAD+ biosynthesis is associated with an increased risk of AKI in patients [115]. In addition, NAD+ can reduce the susceptibility to AKI in aged mice through sirt1, one NAD+-dependent class III histone deacetylases [116]. Of note, prophylactic NAD+ boosting by nicotinamide riboside significantly increased autophagy in the ischemic kidney [117]. Thus, the regulation between NAD+ and autophagy possibly depends on sirt1. Under energy depletion, sirt1 activated by increased NAD+ levels can deacetylate ATG proteins [118,119] and increase autophagy genes expression via forkhead box protein O1 (FOXO1) and FOXO3a [120], leading to the autophagy activation. Sirt1 may also deacetylate STK11 to stimulate AMPK and interact with tuberin to inhibit mTORC1 [121] to regulate autophagy and response to stress [122].

\subsubsection{Other Pathways}

In addition to the energy signaling pathway, other pathways also contribute to the regulation of autophagy. For example, active mitogen-activated protein kinase 8 (MAPK8; also known as JNK1) [123] and death-associated protein kinases (DAP kinases) [124] can activate Beclin 1 to promote autophagy. Some epigenetic mechanisms, kinases, and transcriptional factors are also involved in the regulation of the elongation and fusion stages of autophagy. For example, eukaryotic translation initiation factor 2 subunit- $\alpha$ (eIF2 $\alpha)$ [125] and NF- $\kappa B$ kinase inhibitor (IKK) [126] can induce autophagy by regulating some ATG genes. Transcription factor EB (encoded by TFEB) [127] and nuclear export of zinc-finger protein with KRAB and SCAN domains 3 (encoded byZKSCAN3) [128] regulate autophagy by transcriptional regulation of autophagy/lysosomes genes. In cisplatin-induced AKI, activation of TFEB-mediated autophagy and attenuation of mitochondrial dysfunction by trehalose might depend on the inhibition of Akt [129].

\section{Autophagy in AKI-CKD Transition}

After AKI, injured tubules act as a driving force to promote the progression of AKI to chronic kidney disease [130-133]. In the presence of mild to moderate injury, tubular cells may proliferate to replace apoptotic/necrotic cells, while the cells with severe injury may not recover for proliferation and instead they secrete pro-fibrotic growth factors and inflammatory factors, creating a situation for maladaptive repair [130-134]. The number of autophagosomes was increased in the tubular cells upon and after cisplatin and ischemic AKI [135]. Emerging evidence imply the involvement of autophagy in renal tubular injury and repair during AKI progression to CKD.

Increasing evidence suggests that cell-cycle arrest, especially G2/M arrest, in tubular cells is a pivotal event in maladaptive repair and renal fibrosis through the induction of pro-fibrotic cytokines [136]. Whether autophagy is related to cell cycle arrest and the production of pro-fibrotic cytokines is of interest. Li et al. [15] reported that Atg5 deficiency in proximal tubules promoted cell cycle G2/M arrest and renal fibrosis in UUO mice and AGT II-treated HK2 cells, while Atg5 overexpression reversed this outcome. However, Bao et al. [137] reported that G2/M cell cycle arrest was blocked by autophagy inhibitor 3-MA in rats after hyperuricemic nephropathy. Mechanistically, mTOR-autophagy spatial coupling compartment (TASCC) formation increased in G2/M-arrested renal tubular cells [138], and TASCC disruption reduced production and secretion of pro-fibrotic factors in tubular cells after severe AKI. This finding suggests that autophagy participates in TASCC formation in G2/M cell to facilitate maladaptive kidney repair after AKI. 
In addition to G2/M arrest, cell senescence, a form of permanent cell cycle arrest, may also participate in the development of CKD, including that induced by cisplatin. Senescence not only prevents cell proliferation but also enhances the production of proinflammatory cytokines as part of the senescence-associated secretory phenotype (SASP). Baisantry et al. [15] demonstrated that Atg5 ablation from kidney proximal tubules decreased tubular cell senescence and reduced fibrosis after renal ischemia/reperfusion injury in mice, implying a role of tubular autophagy in senescence and renal fibrosis in post-injury kidneys. More recently, senescent cells in kidneys after repeated low dose cisplatin treatment, which, along with fibrosis, was alleviated by NAC [62] and intermittent Dasatinib + Quercetin treatment [61].

These observations suggest that autophagy might regulate cell cycle arrest and senescence, affecting kidney repair and AKI-CKD transition after kidney injury.

\section{Autophagy in Chronic Kidney Problems Following Cisplatin Treatment}

In addition to AKI, autophagy has also been implicated in the pathogenesis of CKD transition $[8,139]$. However, very limited information is currently available on the role of autophagy in chronic kidney problems following cisplatin treatment.

\subsection{Autophagy in Tubulointerstitial Fibrosis}

One pathological hallmark in CKD is interstitial fibrosis. Accumulation of autophagosomes was observed in kidney tubules with tubulointerstitial fibrosis in the UUO model [14,140]. Several studies using specific autophagy gene knockout models revealed that autophagy might promote the progression of tubulointerstitial fibrosis. Compared to wild-type mice, proximal tubule-specific Atg5 knockout mice had significantly less tubular senescence, less interstitial fibrosis, and improved renal function after renal ischemia/reperfusion injury $[15,16]$. We [14] demonstrated that mice with Atg7 knockout in proximal tubules had fewer atrophic tubules, less apoptosis, and less interstitial fibrosis during UUO. These initial findings are supported by follow-up studies [141-143], indicating that autophagy in kidney tubules promotes interstitial fibrosis. Mechanistically, autophagy may induce tubular cell death, cell cycle arrest, and senescence, resulting in the production and secretion of pro-fibrotic and pro-inflammatory cytokines to stimulate fibroblasts for fibrosis [14,138]. In particular, Canaud et al. [138] demonstrated the formation of the mTOR-autophagy spatial coupling compartment (TASCC) in renal tubular cells that facilitates the production and secretion of pro-fibrotic factors.

In contrast, there are studies showing evidence for an anti-fibrotic role of autophagy in renal disease models. Global LC3B (Atg8) knockout mice and beclin-1 (Atg6) heterozygous mice exhibited a deficit in autophagy activation and developed more severe interstitial fibrosis during UUO [17]. Autophagy may suppress fibrosis by promoting the degradation of extracellular matrix proteins including collagens and fibronectin, key components of fibrosis. To support this, Kim et al. [144] showed that inhibition of autophagy increased collagen deposition in TGF $\beta 1$-treated glomerular mesangial cells (MMC) and in mice during UUO. Additionally, fibronectins, the glycoproteins that connect cells with collagen fibers in the ECM, can also be degraded through autophagy in renal tubular cells [145]. Insight from tubule, Atg5 knockout proximal tubules showed more severe cell cycle arrest with increased interstitial fibrosis during UUO [15], which implies that its anti-fibrotic effect might be due to its function of cell cycle regulation. Moreover, 3-MA treated kidney in the UUO model showed aggravated tubular cell apoptosis and tubulointerstitial fibrosis, which suggests that autophagy might exert its anti-fibrotic effect by suppressing tubular cell injury [146].

Collectively, these findings suggest that persistent activation of autophagy plays a dual role in kidney fibrosis. On one hand, it may suppress fibrosis by promoting the degradation of extracellular matrix proteins and suppress tubular injury. On the other hand, it may promote fibrosis by inducing a secretory phenotype in tubular cells for the release of pro-fibrotic factors. Currently, autophagy in kidney repair after cisplatin nephrotoxicity 
and its progression into CKD has not been investigated. Obviously, research in this area may shed light on clinical treatment for cancer patients after cisplatin chemotherapy.

\subsection{Autophagy and Chronic Inflammation}

As mentioned above, chronic inflammation is a critical factor in the pathogenesis of CKD. In 2015, Brooks et al. [147] demonstrated that KIM-1-mediated phagocytosis led to the activation of autophagy to clear apoptotic cell debris and further induced pro-tolerogenic antigen presentation following renal ischemia-reperfusion injury. This study provided the first evidence for autophagy in downregulation of the inflammatory response and immune tolerance maintenance after kidney injury.

Subsequent studies further proved the mutual regulation between autophagy and chronic inflammation in CKD. Inhibition of NLRP3 inflammasome resulted in the upregulation of HIF1 $\alpha$ and BNIP3-mediated mitophagy, attenuating apoptosis in contrast-induced AKI [148]. Moreover, NLRP3 knockout in kidney tubular cells showed better renal function and up-regulated mitophagy in UUO, providing evidence for the anti-autophagic function of NLRP3 in kidneys [149]. Reciprocally, prohibitin 2 (PHB2), a newly identified intracellular receptor of mitophagy, protected against kidney tubular injury by improving mitochondrial function and inhibiting NLRP3-induced inflammatory pathways induced by angiotensin II [150]. Moreover, ATG5-mediated autophagy inhibited NF- $\mathrm{KB}$ signaling, which alleviated tubular cell inflammation in response to the kidney injury induced by UUO or angiotensin II [151].

To sum up, these findings imply a possible reciprocal regulation between autophagy/ mitophagy and chronic inflammation in CKD progression, although it remains unclear if their regulation is direct or indirect.

\section{Strategies Targeting Autophagy in Cisplatin Nephrotoxicity during Chemotherapy}

Given the critical role of autophagy in cisplatin-induced kidney disease, the pharmacological intervention of autophagy should be a meaningful strategy for the prevention and treatment of kidney diseases during cisplatin chemotherapy. In tumors, autophagy has long been considered a double-edged sword in tumorigenesis and cancer therapy. In the kidney, autophagy is protective during acute cisplatin nephrotoxicity, but the role of autophagy in chronic kidney problems following cisplatin chemotherapy is unclear. Any strategies targeting autophagy in cisplatin chemotherapy must be taken into consideration of the effects in both tumors and normal tissues, especially the kidneys (Figure 3).

\subsection{Activation of Autophagy}

Most pharmacological enhancement of autophagy showed a protective role in the cisplatin-induced kidney injury but makes tumors more sensitive through inhibition of mTOR signaling. However, those drugs might regulate cellular processes beyond autophagy and result in some other effects. For example, mTOR inhibitors, including rapamycin and its analogs everolimus, are widely used autophagy activators. In kidneys, they protect against injury through autophagy but delayed tubular repair following acute injury due to its inhibition of growth and proliferation [152,153]. Additionally, their anti-cancer effects have been well-documented as they prevent tumor cell proliferation and reverse cell senescence [154-156] (Table 2). The interventions about upstream mTOR signaling pathways were also conducted. For example, metformin, commonly prescribed for blood glucose control in diabetes, is one with such properties. In kidneys, metformin protected against kidney injury in NRK-52E through stimulating AMPK phosphorylation and autophagy activation [157]. It lowered cancer risks [158] and enhanced the anti-cancer effects of cisplatin on meningioma cells [159] by activating autophagy through AMPK-mTOR pathways and subsequent series of metabolic responses. Trichostatin A and SAHA (broadspectrum HDAC inhibitors) and Tubastatin A (HDAC6 specific inhibitor) also protects against cisplatin nephrotoxicity in kidneys through AMPK-mTOR pathways but sensitizes cancer cells to cisplatin cytotoxicity by enhancing DNA damage [113,114,160-162]. In 
addition, some natural products, neferine [95,163], emodin [164,165], ginsenoside Rb3 [97], oridonin [98], 3DC2ME [166], scutellarin [167,168], and rottlerin [49,112] also exert the same effect through AKT/ mTOR pathways.

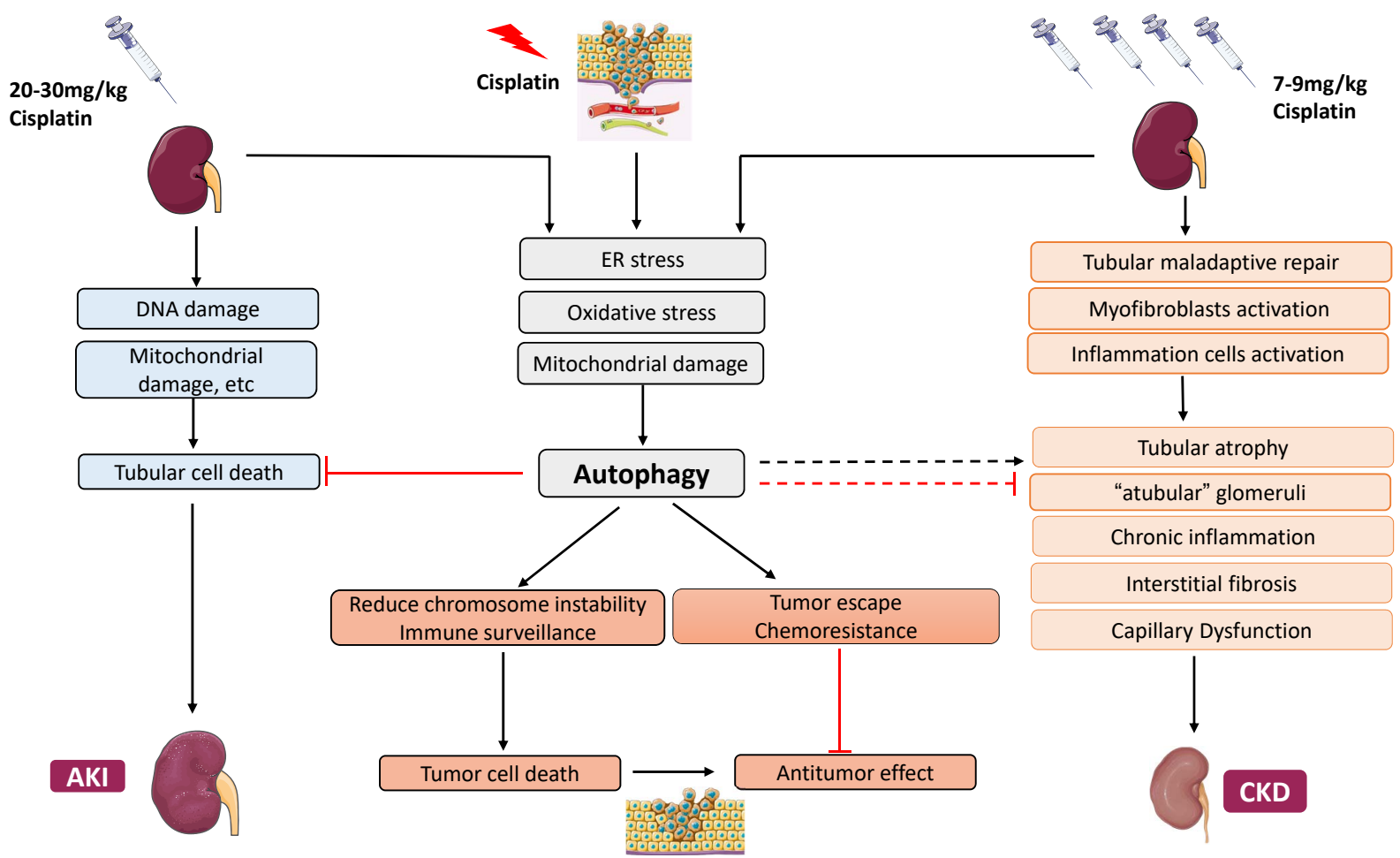

Figure 3. Autophagy in cisplatin-induced nephrotoxicity during cancer therapy. In kidneys, autophagy protects tubular cells against acute kidney injury induced by cisplatin. Autophagy may also affect the development of CKD through its regulation of tubular atrophy, interstitial fibrosis, etc. In cancers, autophagy may suppress tumorigenesis, but it increases the resistance of cancer cells to cisplatin chemotherapy.

Of interest, trehalose regulates autophagy by rapid and transient lysosomal enlargement and membrane permeabilization (LMP) through TFEB, but does not induce mTOR $[129,169]$. Although it still benefited the kidney, it also decreased anti-cancer outcomes. It is worth investigating why autophagy caused by mTOR makes the tumor more sensitive, but autophagy induced by TFEB does not show this. There may be two reasons for this situation. The first is that activation of mTOR regulates the upstream of autophagy to cause tumor more sensitive, while TFEB regulates the downstream lysosomal fusion to promote tumor progression. In this case, the interventions stage of autophagy process is particularly pivotal in tumor treatment. The second is that the tumor-killing effect caused by these drugs may be caused by other effects such as DNA damage and inhibition of cell proliferation but not through autophagy.

Besides the above, autophagy activation in some tumors helps the recognition of cancer cells by the immune system to facilitate the anti-tumor immune surveillance and promote autophagic cell death through various pathways of cell death, including apoptosis, necrosis, and necroptosis $[170,171]$. These effects imply that autophagy might be helpful for cancer prevention and treatment through reducing chromosome instability, increasing immune surveillance, and promoting cell death (Figure 3).

Collectively, although a lot of evidence has shown that drugs that activate autophagy can protect the kidneys and kill tumors, their other pathological effects and whether they play a therapeutic role directly due to autophagy still require in-depth research. 
Table 2. Therapeutic compounds targeting autophagy during cisplatin chemotherapy.

\begin{tabular}{|c|c|c|c|c|c|c|c|}
\hline \multirow{2}{*}{ Compound } & \multicolumn{3}{|c|}{ Kidney } & \multicolumn{3}{|c|}{ Cancer } & \multirow[b]{2}{*}{ Reference } \\
\hline & Model & Effects & Underlying Mechanism & Model & Effects & Underlying Mechanism & \\
\hline \multicolumn{8}{|l|}{ Activate autophagy } \\
\hline Metformin & NRK-52E & Protective & $\begin{array}{l}\text { Stimulate AMPK } \alpha \\
\text { phosphorylation }\end{array}$ & Meningioma cell & Lower cancer risk & AMPK-mTOR pathways & [157-159] \\
\hline Rapamycin & C57BL/6 mice & $\begin{array}{c}\text { Protective } \\
\text { Harmful }\end{array}$ & Inhibition of mTOR & $\begin{array}{l}\text { Breast cancer } \\
\text { Skin tumors }\end{array}$ & Inhibit progression & $\begin{array}{l}\text { 1. Inhibition of mTOR } \\
\text { 2. Decreased } \\
\text { proliferation }\end{array}$ & {$[152,155,172]$} \\
\hline Everolimus & $\begin{array}{c}\text { Wistar/ST rats } \\
\text { HK-2 } \\
\text { NRK-52E }\end{array}$ & harmful & $\begin{array}{l}\text { Inhibition of mTOR to } \\
\text { activates Ulk1 impairing } \\
\text { tubular regeneration after } \\
\text { acute injury }\end{array}$ & $\begin{array}{l}\text { Ovarian cancer } \\
\text { Patients with } \\
\text { Thymoma and } \\
\text { Thymic Carcinoma }\end{array}$ & $\begin{array}{l}\text { 1. Delay } \\
\text { development } \\
\text { 2. Durable disease } \\
\text { control }\end{array}$ & $\begin{array}{l}\text { 1. Inhibition of mTOR } \\
\text { 2. Reverse cell } \\
\text { senescence }\end{array}$ & {$[153,154,156]$} \\
\hline Trichostatin A (TSA) & $\begin{array}{l}\text { C57BL/6mice } \\
\text { Atg7-/- mice }\end{array}$ & Protective & $\begin{array}{l}\text { AMPK activation and } \\
\text { marginal inactivation of } \\
\text { mTOR }\end{array}$ & A2780RES cells & More sensitive & Akt/mTOR Signaling & {$[114,160]$} \\
\hline $\begin{array}{l}\text { Tubastatin A } \\
\text { (TA) }\end{array}$ & $\begin{array}{l}\text { C57BL/ } 6 \\
\text { HK2 cell }\end{array}$ & Protective & $\begin{array}{c}\text { HDAC6 inhibition } \\
\text { decreased renal oxidative } \\
\text { stress and malondialdehyde } \\
\text { levels }\end{array}$ & A549 and H292 cells & More sensitive & Increased DNA damage & {$[114,160]$} \\
\hline Rottlerin & $\begin{array}{c}\text { PT- } A t g 7-\mathrm{KO} \text { mice } \\
\text { RPTCs }\end{array}$ & Protective & $\begin{array}{c}\text { Suppress phosphorylation of } \\
\text { AKT/ mTOR, p70S6 kinase, } \\
\text { and ULK1 }\end{array}$ & $\begin{array}{c}\text { A2780 human } \\
\text { ovarian cancer cells }\end{array}$ & More sensitive & $\begin{array}{l}\text { Inhibit proliferation, } \\
\text { migration, and } \\
\text { metastasis }\end{array}$ & {$[49,112]$} \\
\hline Neferine & NRK-52E cell & Protective & AMPK-mTOR pathways & $\begin{array}{l}\text { Human lung } \\
\text { adenocarcinoma } \\
\text { (A549 cells) }\end{array}$ & More sensitive & AMPK-mTOR pathways & {$[95,163]$} \\
\hline Emodin & NRK-52E & Protective & $\begin{array}{c}\text { Induce the phosphorylation } \\
\text { and activation of AMPK, } \\
\text { decrease mTOR activation }\end{array}$ & $\begin{array}{l}\text { Human bladder } \\
\text { cancer cells } \\
\text { Non-small cell lung } \\
\text { cancer (NSCLC) }\end{array}$ & More sensitive & $\begin{array}{c}\text { ROS elevation and MRP1 } \\
\text { Down-regulation of } \\
\text { ERCC1 and inactivation } \\
\text { of ERK1/2 }\end{array}$ & {$[164,165]$} \\
\hline Ginsenoside Rb3 & $\begin{array}{l}\text { HEK293 cell } \\
\text { ICR mice }\end{array}$ & Protective & Regulation of AMPK/mTOR & Oral Cancer & More sensitive & $\begin{array}{l}\text { Regulation of } \\
\text { AMPK/mTOR }\end{array}$ & [97] \\
\hline
\end{tabular}


Table 2. Cont.

\begin{tabular}{|c|c|c|c|c|c|c|c|}
\hline \multirow{2}{*}{ Compound } & \multicolumn{3}{|c|}{ Kidney } & \multicolumn{3}{|c|}{ Cancer } & \multirow[b]{2}{*}{ Reference } \\
\hline & Model & Effects & Underlying Mechanism & Model & Effects & Underlying Mechanism & \\
\hline Oridonin & $\begin{array}{l}\text { C57BL/ } 6 \text { mice inhibit } \\
\text { A549 cell line activate }\end{array}$ & Protective & $\begin{array}{c}\text { AMPK/Akt/mTOR- } \\
\text { dependent autophagosome } \\
\text { accumulation }\end{array}$ & $\begin{array}{l}\text { Human lung } \\
\text { carcinoma cell }\end{array}$ & More sensitive & $\begin{array}{l}\text { AMPK/Akt/mTOR- } \\
\text { dependent } \\
\text { autophagosome } \\
\text { accumulation }\end{array}$ & [98] \\
\hline 3DC2ME & LLC-PK1 cells & Protective & AMPK/mTOR & - & - & - & [166] \\
\hline Scutellarin & C57BL/6 mice & Protective & JNK, p38, ERK and Stat3. & $\begin{array}{l}\text { Non-small Cell Lung } \\
\text { Cancer }\end{array}$ & More sensitive & $\begin{array}{c}\text { Activate ERK/p53 and } \\
\text { c-met/AKT/mTOR } \\
\text { signaling pathways }\end{array}$ & {$[167,168]$} \\
\hline Trehalose & $\begin{array}{l}\text { C57BL } / 6 \text { mice } \\
\text { HK2 cell }\end{array}$ & Protective & $\begin{array}{l}\text { 1. Activate TFEB-mediated } \\
\text { mitophagy } \\
\text { 2. Attenuate mitochondrial } \\
\text { dysfunction }\end{array}$ & Me21 cells & Protective & $\begin{array}{l}\text { Activate } \\
\text { mTOR-independent } \\
\text { autophagy }\end{array}$ & {$[129,169]$} \\
\hline Oleanolic acid & $\begin{array}{l}\text { BALB/CN mice } \\
\text { Hela cells }\end{array}$ & Protective & $\begin{array}{l}\text { Suppress oxidative stress } \\
\text { and inflammatory response }\end{array}$ & $\begin{array}{l}\text { Hela cells } \\
\text { hepatocellular } \\
\text { carcinoma }\end{array}$ & More sensitive & $\begin{array}{l}\text { Induce autophagic cell } \\
\text { death via mTOR }\end{array}$ & {$[171,173]$} \\
\hline 3-MA & $\begin{array}{l}\text { LLC-PK1 cells } \\
\text { RPTC cells }\end{array}$ & Harmful & $\begin{array}{l}\text { Block autophagosome } \\
\text { formation-PI3K inhibitors }\end{array}$ & $\begin{array}{c}\text { Osteosarcoma cells } \\
\text { Cervical cancer cells } \\
\text { Osteosarcoma } \\
\text { Human ovarian } \\
\text { cancer }\end{array}$ & More sensitive & $\begin{array}{l}\text { Enhanced apoptosis, } \\
\text { reduced cell viability }\end{array}$ & {$[22,26,70,174,175]$} \\
\hline Wortmannin & LLC-PK1 cells & Harmful & $\begin{array}{l}\text { Block autophagosome } \\
\text { formation-PI3K inhibitors }\end{array}$ & $\begin{array}{l}\text { Platinum resistant } \\
\text { ovarian cancer } \\
\text { (PROC) }\end{array}$ & More sensitive & $\begin{array}{l}\text { 1. Inhibit DNA repair } \\
\text { 2. Enhance cellular } \mathrm{CP} \\
\text { uptake }\end{array}$ & [176] \\
\hline LY294002 & LLC-PK1 cells & Harmful & $\begin{array}{l}\text { Block autophagosome } \\
\text { formation-PI3K inhibitors }\end{array}$ & $\begin{array}{l}\text { HCT } 166 \text { human } \\
\text { colon cancer cell }\end{array}$ & More sensitive & $\begin{array}{c}\text { p53 induction by DNA } \\
\text { damage }\end{array}$ & [177] \\
\hline
\end{tabular}


Table 2. Cont.

\begin{tabular}{|c|c|c|c|c|c|c|c|}
\hline \multirow{2}{*}{ Compound } & \multicolumn{3}{|c|}{ Kidney } & \multicolumn{3}{|c|}{ Cancer } & \multirow[b]{2}{*}{ Reference } \\
\hline & Model & Effects & Underlying Mechanism & Model & Effects & Underlying Mechanism & \\
\hline Bafilomycin (BAF) & RPTC cells & Harmful & $\begin{array}{c}\text { Block fusion of the } \\
\text { autophagosome with } \\
\text { lysosome }\end{array}$ & $\begin{array}{l}\text { Human bladder } \\
\text { cancer }\end{array}$ & More sensitive & $\begin{array}{l}\text { Enhanced apoptosis, } \\
\text { reduced cell viability }\end{array}$ & {$[70,178]$} \\
\hline $\begin{array}{l}\text { Chloroquine } \\
\text { (CQ) }\end{array}$ & $\begin{array}{l}\text { C57BL / } 6 \text { mice } \\
\text { Adult Wistar rats }\end{array}$ & Harmful & Block autophagic flux & $\begin{array}{c}\text { Human bladder } \\
\text { cancer } \\
\text { Endometrial cancer } \\
\text { Osteosarcoma } \\
\text { Nasopharyngeal } \\
\text { carcinoma } \\
\text { Human gastric } \\
\text { cancer } \\
\text { Cervical cancer cells }\end{array}$ & More sensitive & $\begin{array}{l}\text { 1. Block autophagic flux } \\
\text { 2. Autophagy- } \\
\text { independent manner }\end{array}$ & {$[18,175,178-185]$} \\
\hline Morin hydrate & $\begin{array}{c}\text { HEK-293 } \\
\text { Male ICR mice }\end{array}$ & Protective & $\begin{array}{l}\text { Phosphorylation and } \\
\text { activation of AMPK }\end{array}$ & $\begin{array}{l}\text { Hepatocellular } \\
\text { Carcinoma }\end{array}$ & More sensitive & $\begin{array}{c}\text { 1. Impairing } \\
\text { PARP1/HMGB1- } \\
\text { dependent autophagy } \\
\text { 2. Reverses Cisplatin } \\
\text { Resistance }\end{array}$ & {$[99,186]$} \\
\hline
\end{tabular}

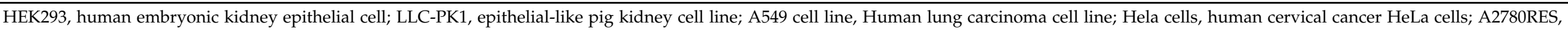
cisplatin-resistant human ovarian cancer cells; T or TC, advanced/recurrent thymoma (T) or thymic carcinoma (TC); and Me21, melanoma cells. 


\subsection{Inhibition of Autophagy}

Before tumorigenesis, autophagy defects result in poor elimination of oncogenic proteins, toxic aggregates, and damaged organelles, leading to chronic inflammation, tissue damage, genome instability, and oncogenic gene activation $[187,188]$. However, autophagy also supports metabolism and survival in cancer cells once the tumor has formed [185]. In this case, autophagy protects cancer cells and increases their resistance to anticancer drugs, and inhibition of autophagy would sensitize cancer cells to therapy and enhance the therapeutic effect of chemotherapeutics.

Multiple studies have demonstrated the evidence for the role of autophagy in cisplatin resistance in chemotherapy. Most animal studies and clinical trials focused on chloroquine (CQ), which blocked autophagic flux and sensitized cancers to cisplatin treatment $[18,175,178-185]$. Bafilomycin A1, which inhibits autophagy by attenuating the fusion of autophagosome with lysosome, sensitized human bladder cancer cells to cisplatin toxicity [21]. The PI3K pathway is abnormally active in many types of cancers, and PI3K inhibitors block autophagosome formation, thus making PI3K inhibitors attractive targets for cancer therapy through suppressing tumor growth while inhibiting autophagy from sensitizing cancer cells to cisplatin treatment. 3-MA, a P3K inhibitor, enhanced apoptosis and reduced cell viability in cancers $[26,174,175,189]$. Platinum-resistant ovarian cancer was more sensitive to cisplatin when co-administrated with wortmannin (another PI3K inhibitor) [176], although whether this synergistic effect is due to autophagy inhibition by wortmannin was not determined.

From the current findings, many drugs that inhibit autophagy can decrease the resistance of tumors to cisplatin but can cause damage to acute kidney injury. The function of autophagy in chronic kidney problems following cisplatin treatment remains unclear, but there is evidence for the involvement of autophagy in the development of CKD after kidney injury. In this regard, although inhibiting autophagy aggravates acute kidney injury, it may protect the progression of chronic kidney injury. Therefore, it carefully avoids using autophagy inhibitors in patients with tumors and acute kidney injury, but it may be a promising option for patients with chronic kidney disease. Therefore, it is imperative to verify the role of autophagy in chronic kidney disease.

\subsection{Therapeutic Potential and Challenges}

Despite the progress in research, therapies targeting autophagy remain challenging. First, autophagy might have different roles depending on the disease stage. Autophagy is renoprotective during AKI, but sustained autophagy activation after AKI might promote renal fibrosis or maladaptive kidney repair. It would be beneficial to enhance autophagy during the acute phase of injury but to limit autophagy during kidney repair. It is essential to define these disease phases for appropriate intervention. Second, some autophagytargeting agents might have other or off-target effects. Due to this, it is sometimes difficult to determine whether the effects of drugs are caused via autophagy or other effects. For example, mTOR inhibitors might protect against AKI by activating autophagy, but they may also prevent kidney repair due to inhibition of cell growth and proliferation $[153,154,156]$. Third, inhibition of autophagy may sensitize tumors to cisplatin chemotherapy, but it blocks a protective mechanism in kidneys. In this regard, it is crucial to have site-specific delivery of drugs for therapeutic efficacy and safety. Tumor-targeted nanoparticles encapsulated with autophagy inhibitors may emerge as a promising tool to minimize nephrotoxicity during cisplatin chemotherapy. Finally, more clinical trials should be conducted to test, verify and translate those meaningful findings to humans.

\section{Conclusions}

In this review, we have summarized and analyzed the current research about the role and regulation of autophagy in cisplatin-induced AKI and CKD during cancer therapy. Autophagy protects against cisplatin-induced AKI, but its role in CKD development following 
cisplatin chemotherapy remains unclear. In the future, studies based on tumor-bearing animal models and clinical trials are necessary to determine the safety and effectiveness of autophagy modulators in the kidney and their anti-tumor effects during cisplatin treatment.

Author Contributions: X.H. and Z.D. contributed to the conceptualization, design and outline of this review. X.H. prepared the original draft with figures. X.H., Z.M., L.W., S.L. and Z.D. contributed to revision and editing. All authors have read and agreed to the published version of the manuscript.

Funding: The authors were partly supported by the grants from China Scholarship Council, the National Institutes of Health of USA (DK058831, DK087843), and Department of Veterans Administration of USA (000319). Z.D. is a recipient of Senior Research Career Scientist award of Department of Veterans Administration of USA.

Conflicts of Interest: The authors declare no conflict of interest.

\section{References}

1. Dasari, S.; Tchounwou, P.B. Cisplatin in cancer therapy: Molecular mechanisms of action. Eur. J. Pharmacol. 2014, 740, 364-378. [CrossRef]

2. Cohen, S.M.; Lippard, S.J. Cisplatin: From DNA damage to cancer chemotherapy. Prog. Nucleic Acid. Res. Mol. Biol. 2001, 67, 93-130. [CrossRef]

3. de Jonge, M.J.; Verweij, J. Renal Toxicities of Chemotherapy. Semin. Oncol. 2006, 33, 68-73. [CrossRef] [PubMed]

4. Mehta, R.L.; Kellum, J.A.; Shah, S.V.; Molitoris, B.A.; Ronco, C.; Warnock, D.G.; Levin, A. Acute Kidney Injury Network: Report of an initiative to improve outcomes in acute kidney injury. Crit. Care 2007, 11, R31. [CrossRef] [PubMed]

5. Latcha, S.; Jaimes, E.A.; Patil, S.; Glezerman, I.G.; Mehta, S.; Flombaum, C.D. Long-Term Renal Outcomes after Cisplatin Treatment. Clin. J. Am. Soc. Nephrol. 2016, 11, 1173-1179. [CrossRef] [PubMed]

6. Mizushima, N.; Komatsu, M. Autophagy: Renovation of Cells and Tissues. Cell 2011, 147, 728-741. [CrossRef] [PubMed]

7. Mizushima, N.; Levine, B.; Cuervo, A.M.; Klionsky, D.J. Autophagy fights disease through cellular self-digestion. Nature 2008, 451, 1069-1075. [CrossRef]

8. Tang, C.; Livingston, M.J.; Liu, Z.; Dong, Z. Autophagy in kidney homeostasis and disease. Nat. Rev. Nephrol. 2020, 16, 489-508. [CrossRef]

9. Kaushal, G.P.; Shah, S.V. Autophagy in acute kidney injury. Kidney Int. 2016, 89, 779-791. [CrossRef]

10. Huber, T.B.; Edelstein, C.L.; Hartleben, B.; Inoki, K.; Jiang, M.; Koya, D.; Kume, S.; Lieberthal, W.; Pallet, N.; Quiroga, A.; et al. Emerging role of autophagy in kidney function, diseases and aging. Autophagy 2012, 8, 1009-1031. [CrossRef]

11. Periyasamy-Thandavan, S.; Jiang, M.; Schoenlein, P.; Dong, Z. Autophagy: Molecular machinery, regulation, and implications for renal pathophysiology. Am. J. Physiol. Physiol. 2009, 297, F244-F256. [CrossRef]

12. Nam, S.A.; Kim, W.-Y.; Kim, J.W.; Park, S.H.; Kim, H.L.; Lee, M.-S.; Komatsu, M.; Ha, H.; Lim, J.H.; Park, C.W.; et al. Autophagy attenuates tubulointerstital fibrosis through regulating transforming growth factor- $\beta$ and NLRP3 inflammasome signaling pathway. Cell Death Dis. 2019, 10,1-10. [CrossRef]

13. Li, L.; Kang, H.; Zhang, Q.; D'Agati, V.D.; Al-Awqati, Q.; Lin, F. FoxO3 activation in hypoxic tubules prevents chronic kidney disease. J. Clin. Investig. 2019, 129, 2374-2389. [CrossRef]

14. Livingston, M.J.; Ding, H.-F.; Huang, S.; Hill, J.A.; Yin, X.-M.; Dong, Z. Persistent activation of autophagy in kidney tubular cells promotes renal interstitial fibrosis during unilateral ureteral obstruction. Autophagy 2016, 12, 976-998. [CrossRef]

15. Li, H.; Peng, X.; Wang, Y.; Cao, S.; Xiong, L.; Fan, J.; Wang, Y.; Zhuang, S.; Yu, X.; Mao, H. Atg5-mediated autophagy deficiency in proximal tubules promotes cell cycle G2/M arrest and renal fibrosis. Autophagy 2016, 12, 1472-1486. [CrossRef] [PubMed]

16. Baisantry, A.; Bhayana, S.; Rong, S.; Ermeling, E.; Wrede, C.; Hegermann, J.; Pennekamp, P.; Sörensen-Zender, I.; Haller, H.; Melk, A.; et al. Autophagy Induces Prosenescent Changes in Proximal Tubular S3 Segments. J. Am. Soc. Nephrol. 2015, 27, 1609-1616. [CrossRef] [PubMed]

17. Ding, Y.; Kim, S.L.; Lee, S.-Y.; Koo, J.K.; Wang, Z.; Choi, M.E. Autophagy Regulates TGF- $\beta$ Expression and Suppresses Kidney Fibrosis Induced by Unilateral Ureteral Obstruction. J. Am. Soc. Nephrol. 2014, 25, 2835-2846. [CrossRef]

18. Sui, X.; Chen, R.; Wang, Z.; Huang, Z.; Kong, N.; Zhang, M.; Han, W.; Lou, F.; Yang, J.; Zhang, Q.; et al. Autophagy and chemotherapy resistance: A promising therapeutic target for cancer treatment. Cell Death Dis. 2013, 4, e838. [CrossRef] [PubMed]

19. O'Donovan, T.R.; O'Sullivan, G.C.; McKenna, S.L. Induction of autophagy by drug-resistant esophageal cancer cells promotes their survival and recovery following treatment with chemotherapeutics. Autophagy 2011, 7, 509-524. [CrossRef]

20. Sirichanchuen, B.; Pengsuparp, T.; Chanvorachote, P. Long-term cisplatin exposure impairs autophagy and causes cisplatin resistance in human lung cancer cells. Mol. Cell Biochem. 2012, 364, 11-18. [CrossRef]

21. Wang, J.; Wu, G.S. Role of Autophagy in Cisplatin Resistance in Ovarian Cancer Cells. J. Biol. Chem. 2014, 289, 17163-17173. [CrossRef]

22. Jiang, K.; Zhang, C.; Yu, B.; Chen, B.; Liu, Z.; Hou, C.; Wang, F.; Shen, H.; Chen, Z. Autophagic degradation of FOXO3a represses the expression of PUMA to block cell apoptosis in cisplatin-resistant osteosarcoma cells. Am. J. Cancer Res. 2017, 7, 1407-1422. [PubMed] 
23. Levine, B.; Kroemer, G. Autophagy in the Pathogenesis of Disease. Cell 2008, 132, 27-42. [CrossRef] [PubMed]

24. Beyer, J.; Rick, O.; Weinknecht, S.; Kingreen, D.; Lenz, K.; Siegert, W. Nephrotoxicity after high-dose carboplatin, etoposide and ifosfamide in germ-cell tumors: Incidence and implications for hematologic recovery and clinical outcome. Bone Marrow Transplant. 1997, 20, 813-819. [CrossRef]

25. Campdera, F.J.G.; Gonzalez, P.; Carrillo, A.; Estelles, M.C.; Rengel, M. Cisplatin nephrotoxicity: Symptomatic hypomagnesemia and renal failure. Int. J. Pediatr. Nephrol. 1986, 7, 151-152. [PubMed]

26. Brilleta, G.; Demya, G.; Jacquiauda, C.; Mignotb, L.; Bunkera, D.; Meilletc, D.; Raymond, F.; Jacobs, C.; Brillet, G.; Deray, G.; et al. Long-Term Renal Effect of Cisplatin in Man. Am. J. Nephrol. 1994, 14, 81-84. [CrossRef] [PubMed]

27. Bellomo, R.; Kellum, J.A.; Ronco, C. Acute kidney injury. Lancet 2012, 380, 756-766. [CrossRef]

28. Linkermann, A.; Chen, G.; Dong, G.; Kunzendorf, U.; Krautwald, S.; Dong, Z. Regulated Cell Death in AKI. J. Am. Soc. Nephrol. 2014, 25, 2689-2701. [CrossRef]

29. Zuk, A.; Bonventre, J.V. Acute Kidney Injury. Annu. Rev. Med. 2016, 67, 293-307. [CrossRef]

30. Lieberthal, W.; Nigam, S.K. Acute Renal Failure. I. Relative importance of proximal vs. distal tubular injury. Am. J. Physiol. Physiol. 1998, 275, F623-F632. [CrossRef]

31. Lieberthal, W.; Nigam, S.K. Acute Renal Failure. II. Experimental models of acute renal failure: Imperfect but indispensable. Am. J. Physiol. Physiol. 2000, 278, F1-F12. [CrossRef]

32. Ozkok, A.; Edelstein, C.L. Pathophysiology of Cisplatin-Induced Acute Kidney Injury. BioMed Res. Int. 2014, 2014, 1-17. [CrossRef]

33. Pabla, N.; Dong, Z. Cisplatin nephrotoxicity: Mechanisms and renoprotective strategies. Kidney Int. 2008, 73, 994-1007. [CrossRef] [PubMed]

34. Ciarimboli, G.; Ludwig, T.; Lang, D.; Pavenstädt, H.; Koepsell, H.; Piechota, H.-J.; Haier, J.; Jaehde, U.; Zisowsky, J.; Schlatter, E. Cisplatin Nephrotoxicity Is Critically Mediated via the Human Organic Cation Transporter 2. Am. J. Pathol. 2005, 167, 1477-1484. [CrossRef]

35. Pabla, N.; Murphy, R.F.; Liu, K.; Dong, Z. The copper transporter Ctr1 contributes to cisplatin uptake by renal tubular cells during cisplatin nephrotoxicity. Am. J. Physiol. Physiol. 2009, 296, F505-F511. [CrossRef] [PubMed]

36. Townsend, D.M.; Deng, M.; Zhang, L.; Lapus, M.G.; Hanigan, M.H. Metabolism of Cisplatin to a Nephrotoxin in Proximal Tubule Cells. J. Am. Soc. Nephrol. 2003, 14, 1-10. [CrossRef]

37. Wang, D.; Lippard, S.J. Cellular processing of platinum anticancer drugs. Nat. Rev. Drug Discov. 2005, 4, 307-320. [CrossRef] [PubMed]

38. Yan, M.; Tang, C.; Ma, Z.; Huang, S.; Dong, Z. DNA damage response in nephrotoxic and ischemic kidney injury. Toxicol. Appl. Pharmacol. 2016, 313, 104-108. [CrossRef]

39. Zhu, S.; Pabla, N.; Tang, C.; He, L.; Dong, Z. DNA damage response in cisplatin-induced nephrotoxicity. Arch. Toxicol. 2015, 89, 2197-2205. [CrossRef]

40. Ju, S.-M.; Kim, M.-S.; Jo, Y.-S.; Jeon, Y.-M.; Bae, J.-S.; Pae, H.-O.; Jeon, B.-H. Licorice and its active compound glycyrrhizic acid ameliorates cisplatin-induced nephrotoxicity through inactivation of p53 by scavenging ROS and overexpression of p21 in human renal proximal tubular epithelial cells. Eur. Rev. Med. Pharmacol. Sci. 2017, 21, 890-899.

41. Francescato, H.D.; Costa, R.S.; Silva, C.G.; Coimbra, T.M. Treatment with a p38 MAPK inhibitor attenuates cisplatin nephrotoxicity starting after the beginning of renal damage. Life Sci. 2009, 84, 590-597. [CrossRef] [PubMed]

42. Jiang, M.; Dong, Z. Regulation and Pathological Role of p53 in Cisplatin Nephrotoxicity. J. Pharmacol. Exp. Ther. 2008, 327, 300-307. [CrossRef] [PubMed]

43. Wei, Q.; Dong, G.; Yang, T.; Megyesi, J.; Price, P.M.; Dong, Z. Activation and involvement of p53 in cisplatin-induced nephrotoxicity. Am. J. Physiol. Physiol. 2007, 293, F1282-F1291. [CrossRef] [PubMed]

44. Xu, Y.; Ma, H.; Shao, J.; Wu, J.; Zhou, L.; Zhang, Z.; Wang, Y.; Huang, Z.; Ren, J.; Liu, S.; et al. A Role for Tubular Necroptosis in Cisplatin-Induced AKI. J. Am. Soc. Nephrol. 2015, 26, 2647-2658. [CrossRef] [PubMed]

45. Deng, F.; Sharma, I.; Dai, Y.; Yang, M.; Kanwar, Y.S. Myo-inositol oxygenase expression profile modulates pathogenic ferroptosis in the renal proximal tubule. J. Clin. Investig. 2019, 129, 5033-5049. [CrossRef]

46. Takai, N.; Abe, K.; Tonomura, M.; Imamoto, N.; Fukumoto, K.; Ito, M.; Momosaki, S.; Fujisawa, K.; Morimoto, K.; Takasu, N.; et al. Imaging of reactive oxygen species using $\left[{ }^{3} \mathrm{H}\right]$ hydromethidine in mice with cisplatin-induced nephrotoxicity. EJNMMI Res. 2015, 5, 38. [CrossRef]

47. Yan, M.; Shu, S.; Guo, C.; Tang, C.; Dong, Z. Endoplasmic reticulum stress in ischemic and nephrotoxic acute kidney injury. Ann. Med. 2018, 50, 381-390. [CrossRef]

48. Zsengellér, Z.K.; Ellezian, L.; Brown, D.; Horváth, B.; Mukhopadhyay, P.; Kalyanaraman, B.; Parikh, S.M.; Karumanchi, S.A.; Stillman, I.E.; Pacher, P. Cisplatin Nephrotoxicity Involves Mitochondrial Injury with Impaired Tubular Mitochondrial Enzyme Activity. J. Histochem. Cytochem. 2012, 60, 521-529. [CrossRef]

49. Pabla, N.; Dong, G.; Jiang, M.; Huang, S.; Kumar, M.V.; Messing, R.; Dong, Z. Inhibition of PKC $\delta$ reduces cisplatin-induced nephrotoxicity without blocking chemotherapeutic efficacy in mouse models of cancer. J. Clin. Investig. 2011, 121, $2709-2722$. [CrossRef]

50. Landau, S.I.; Guo, X.; Velazquez, H.; Torres, R.; Olson, E.; Garcia-Milian, R.; Moeckel, G.; Desir, G.V.; Safirstein, R. Regulated necrosis and failed repair in cisplatin-induced chronic kidney disease. Kidney Int. 2019, 95, 797-814. [CrossRef] 
51. Fu, Y.; Cai, J.; Li, F.; Liu, Z.; Shu, S.; Wang, Y.; Liu, Y.; Tang, C.; Dong, Z. Chronic effects of repeated low-dose cisplatin treatment in mouse kidneys and renal tubular cells. Am. J. Physiol. Physiol. 2019, 317, F1582-F1592. [CrossRef]

52. Black, L.M.; Lever, J.M.; Traylor, A.M.; Chen, B.; Yang, Z.; Esman, S.K.; Jiang, Y.; Cutter, G.R.; Boddu, R.; George, J.F.; et al. Divergent effects of AKI to CKD models on inflammation and fibrosis. Am. J. Physiol. Physiol. 2018, 315, F1107-F1118. [CrossRef]

53. Torres, R.; Velazquez, H.; Chang, J.J.; Levene, M.J.; Moeckel, G.; Desir, G.V.; Safirstein, R. Three-Dimensional Morphology by Multiphoton Microscopy with Clearing in a Model of Cisplatin-Induced CKD. J. Am. Soc. Nephrol. 2015, 27, 1102-1112. [CrossRef]

54. Sharp, C.N.; Doll, M.A.; Dupre, T.; Shah, P.P.; Subathra, M.; Siow, D.; Arteel, G.E.; Megyesi, J.; Beverly, L.J.; Siskind, L.J. Repeated administration of low-dose cisplatin in mice induces fibrosis. Am. J. Physiol. Physiol. 2016, 310, F560-F568. [CrossRef]

55. Katagiri, D.; Hamasaki, Y.; Doi, K.; Negishi, K.; Sugaya, T.; Nangaku, M.; Noiri, E. Interstitial renal fibrosis due to multiple cisplatin treatments is ameliorated by semicarbazide-sensitive amine oxidase inhibition. Kidney Int. 2016, 89, 374-385. [CrossRef]

56. Sharp, C.N.; Doll, M.; Dupre, T.V.; Beverly, L.J.; Siskind, L.J. Moderate aging does not exacerbate cisplatin-induced kidney injury or fibrosis despite altered inflammatory cytokine expression and immune cell infiltration. Am. J. Physiol. Physiol. 2019, 316, F162-F172. [CrossRef]

57. Sears, S.M.; Sharp, C.N.; Krueger, A.; Oropilla, G.B.; Saforo, D.; Doll, M.A.; Megyesi, J.; Beverly, L.J.; Siskind, L.J. C57BL/6 mice require a higher dose of cisplatin to induce renal fibrosis and CCL2 correlates with cisplatin-induced kidney injury. Am. J. Physiol. Physiol. 2020, 319, F674-F685. [CrossRef] [PubMed]

58. Menshikh, A.; Scarfe, L.; Delgado, R.; Finney, C.; Zhu, Y.; Yang, H.; De Caestecker, M.P. Capillary rarefaction is more closely associated with CKD progression after cisplatin, rhabdomyolysis, and ischemia-reperfusion-induced AKI than renal fibrosis. Am. J. Physiol. Physiol. 2019, 317, F1383-F1397. [CrossRef] [PubMed]

59. Sharp, C.N.; Doll, M.A.; Megyesi, J.; Oropilla, G.B.; Beverly, L.J.; Siskind, L.J. Subclinical kidney injury induced by repeated cisplatin administration results in progressive chronic kidney disease. Am. J. Physiol. Physiol. 2018, 315, F161-F172. [CrossRef] [PubMed]

60. Kawai, Y.; Satoh, T.; Hibi, D.; Ohno, Y.; Kohda, Y.; Miura, K.; Gemba, M. The effect of antioxidant on development of fibrosis by cisplatin in rats. J. Pharmacol. Sci. 2009, 111, 433-439. [CrossRef] [PubMed]

61. Li, C.; Shen, Y.; Huang, L.; Liu, C.; Wang, J. Senolytic therapy ameliorates renal fibrosis postacute kidney injury by alleviating renal senescence. FASEB J. 2020, 35, e21229. [CrossRef]

62. Li, C.; Xie, N.; Li, Y.; Liu, C.; Hou, F.F.; Wang, J. N-acetylcysteine ameliorates cisplatin-induced renal senescence and renal interstitial fibrosis through sirtuin1 activation and p53 deacetylation. Free Radic. Biol. Med. 2018, 130, 512-527. [CrossRef] [PubMed]

63. Dikic, I.; Elazar, Z. Mechanism and medical implications of mammalian autophagy. Nat. Rev. Mol. Cell Biol. 2018, 19, 349-364. [CrossRef]

64. Oku, M.; Sakai, Y. Three Distinct Types of Microautophagy Based on Membrane Dynamics and Molecular Machineries. BioEssays 2018, 40, e1800008. [CrossRef]

65. Cuervo, A.M.; Dice, J.F. A Receptor for the Selective Uptake and Degradation of Proteins by Lysosomes. Science 1996, 273, 501-503. [CrossRef] [PubMed]

66. Biazik-Richmond, J.; Ylä-Anttila, P.; Vihinen, H.; Jokitalo, E.; Eskelinen, E.-L. Ultrastructural relationship of the phagophore with surrounding organelles. Autophagy 2015, 11, 439-451. [CrossRef]

67. Russell, R.; Tian, Y.; Yuan, H.; Park, H.W.; Chang, Y.-Y.; Kim, J.; Kim, H.; Neufeld, T.P.; Dillin, A.; Guan, K.-L. ULK1 induces autophagy by phosphorylating Beclin-1 and activating VPS34 lipid kinase. Nature 2013, 15, 741-750. [CrossRef] [PubMed]

68. Walczak, M.; Martens, S. Dissecting the role of the Atg12-Atg5-Atg16 complex during autophagosome formation. Autophagy 2013, 9, 424-425. [CrossRef]

69. Yang, C.; Kaushal, V.; Shah, S.V.; Kaushal, G.P. Autophagy is associated with apoptosis in cisplatin injury to renal tubular epithelial cells. Am. J. Physiol. Physiol. 2008, 294, F777-F787. [CrossRef]

70. Periyasamy-Thandavan, S.; Jiang, M.; Wei, Q.; Smith, R.; Yin, X.-M.; Dong, Z. Autophagy is cytoprotective during cisplatin injury of renal proximal tubular cells. Kidney Int. 2008, 74, 631-640. [CrossRef]

71. Baliga, R.; Ueda, N.; Walker, P.D.; Shah, S.V. Oxidant mechanisms in toxic acute renal failure. Am. J. Kidney Dis. 1997, $29,465-477$. [CrossRef]

72. Bolisetty, S.; Traylor, A.M.; Kim, J.; Joseph, R.; Ricart, K.; Landar, A.; Agarwal, A. Heme Oxygenase-1 Inhibits Renal Tubular Macroautophagy in Acute Kidney Injury. J. Am. Soc. Nephrol. 2010, 21, 1702-1712. [CrossRef]

73. Kim, T.-W.; Kim, Y.-J.; Kim, H.-T.; Park, S.-R.; Lee, M.-Y.; Park, Y.-D.; Lee, C.-H.; Jung, J.-Y. NQO1 Deficiency Leads Enhanced Autophagy in Cisplatin-Induced Acute Kidney Injury Through the AMPK/TSC2/mTOR Signaling Pathway. Antioxid. Redox Signal. 2016, 24, 867-883. [CrossRef]

74. Rovetta, F.; Stacchiotti, A.; Consiglio, A.; Cadei, M.; Grigolato, P.G.; Lavazza, A.; Rezzani, R.; Aleo, M.F. ER signaling regulation drives the switch between autophagy and apoptosis in NRK-52E cells exposed to cisplatin. Exp. Cell Res. 2012, 318, 238-250. [CrossRef]

75. Pallet, N.; Bouvier, N.; Legendre, C.; Gilleron, J.; Codogno, P.; Beaune, P.; Thervet, E.; Anglicheau, D. Autophagy protects renal tubular cells against cyclosporine toxicity. Autophagy 2008, 4, 783-791. [CrossRef] 
76. Chandrika, B.B.; Yang, C.; Ou, Y.; Feng, X.; Muhoza, D.; Holmes, A.F.; Theus, S.; Deshmukh, S.; Haun, R.S.; Kaushal, G.P. Endoplasmic Reticulum Stress-Induced Autophagy Provides Cytoprotection from Chemical Hypoxia and Oxidant Injury and Ameliorates Renal Ischemia-Reperfusion Injury. PLoS ONE 2015, 10, e0140025. [CrossRef]

77. Kawakami, T.; Inagi, R.; Takano, H.; Sato, S.; Ingelfinger, J.R.; Fujita, T.; Nangaku, M. Endoplasmic reticulum stress induces autophagy in renal proximal tubular cells. Nephrol. Dial. Transplant. 2009, 24, 2665-2672. [CrossRef] [PubMed]

78. Deegan, S.; Saveljeva, S.; Gorman, A.; Samali, A. Stress-induced self-cannibalism: On the regulation of autophagy by endoplasmic reticulum stress. Cell. Mol. Life Sci. 2012, 70, 2425-2441. [CrossRef]

79. Gozuacik, D.; Bialik, S.; Raveh, T.; Mitou, G.; Shohat, G.; Sabanay, H.; Mizushima, N.; Yoshimori, T.; Kimchi, A. DAP-kinase is a mediator of endoplasmic reticulum stress-induced caspase activation and autophagic cell death. Cell Death Differ. 2008, 15, 1875-1886. [CrossRef]

80. Zhan, M.; Brooks, C.; Liu, F.; Sun, L.; Dong, Z. Mitochondrial dynamics: Regulatory mechanisms and emerging role in renal pathophysiology. Kidney Int. 2013, 83, 568-581. [CrossRef]

81. Tang, C.; Cai, J.; Yin, X.-M.; Weinberg, J.M.; Venkatachalam, M.A.; Dong, Z. Mitochondrial quality control in kidney injury and repair. Nat. Rev. Nephrol. 2020, 17, 299-318. [CrossRef]

82. Wang, Y.; Cai, J.; Tang, C.; Dong, Z. Mitophagy in Acute Kidney Injury and Kidney Repair. Cells 2020, 9, 338. [CrossRef]

83. Brooks, C.; Wei, Q.; Cho, S.-G.; Dong, Z. Regulation of mitochondrial dynamics in acute kidney injury in cell culture and rodent models. J. Clin. Investig. 2009, 119, 1275-1285. [CrossRef] [PubMed]

84. Hall, A.M.; Schuh, C.-D. Mitochondria as therapeutic targets in acute kidney injury. Curr. Opin. Nephrol. Hypertens. 2016, 25, 355-362. [CrossRef]

85. Zhao, C.; Chen, Z.; Qi, J.; Duan, S.; Huang, Z.; Zhang, C.; Wu, L.; Zeng, M.; Zhang, B.; Wang, N.; et al. Drp1-dependent mitophagy protects against cisplatin-induced apoptosis of renal tubular epithelial cells by improving mitochondrial function. Oncotarget 2017, 8, 20988-21000. [CrossRef]

86. Gomes, L.C.; Scorrano, L. High levels of Fis1, a pro-fission mitochondrial protein, trigger autophagy. Biochim. Biophys. Acta (BBA) Bioenerg. 2008, 1777, 860-866. [CrossRef] [PubMed]

87. Westermann, B. Mitochondrial fusion and fission in cell life and death. Nat. Rev. Mol. Cell Biol. 2010, 11, 872-884. [CrossRef] [PubMed]

88. Tran, M.; Tam, D.; Bardia, A.; Bhasin, M.; Rowe, G.; Kher, A.; Zsengeller, Z.; Akhavan-Sharif, M.R.; Khankin, E.; Saintgeniez, M.; et al. PGC-1 $\alpha$ promotes recovery after acute kidney injury during systemic inflammation in mice. J. Clin. Investig. 2011, 121, 4003-4014. [CrossRef] [PubMed]

89. Tran, M.; Zsengeller, Z.; Berg, A.H.; Khankin, E.; Bhasin, M.; Kim, W.; Clish, C.; Stillman, I.E.; Karumanchi, S.A.; Rhee, E.P.; et al. PGC1 $\alpha$ drives NAD biosynthesis linking oxidative metabolism to renal protection. Nature 2016, 531, 528-532. [CrossRef]

90. Reyes-Fermín, L.M.; Avila-Rojas, S.H.; Aparicio-Trejo, O.E.; Tapia, E.; Rivero, I.; Pedraza-Chaverri, J. The Protective Effect of Alpha-Mangostin against Cisplatin-Induced Cell Death in LLC-PK1 Cells is Associated to Mitochondrial Function Preservation. Antioxidants 2019, 8, 133. [CrossRef]

91. Lynch, M.R.; Tran, M.T.; Ralto, K.M.; Zsengeller, Z.K.; Raman, V.; Bhasin, S.S.; Sun, N.; Chen, X.; Brown, D.; Rovira, I.I.; et al. TFEB-driven lysosomal biogenesis is pivotal for PGC1 $\alpha$-dependent renal stress resistance. JCI Insight 2019, 4, e126749. [CrossRef]

92. Jiang, M.; Wei, Q.; Dong, G.; Komatsu, M.; Su, Y.; Dong, Z. Autophagy in proximal tubules protects against acute kidney injury. Kidney Int. 2012, 82, 1271-1283. [CrossRef]

93. Herzog, C.; Yang, C.; Holmes, A.; Kaushal, G.P. zVAD-fmk prevents cisplatin-induced cleavage of autophagy proteins but impairs autophagic flux and worsens renal function. Am. J. Physiol. Physiol. 2012, 303, F1239-F1250. [CrossRef] [PubMed]

94. Wang, Y.; Tang, C.; Cai, J.; Chen, G.; Zhang, D.; Zhang, Z.; Dong, Z. PINK1/Parkin-mediated mitophagy is activated in cisplatin nephrotoxicity to protect against kidney injury. Cell Death Dis. 2018, 9, 1-14. [CrossRef] [PubMed]

95. Li, H.; Tang, Y.; Wen, L.; Kong, X.; Chen, X.; Liu, P.; Zhou, Z.; Chen, W.; Xiao, C.; Xiao, P.; et al. Neferine reduces cisplatin-induced nephrotoxicity by enhancing autophagy via the AMPK/mTOR signaling pathway. Biochem. Biophys. Res. Commun. 2017, 484, 694-701. [CrossRef]

96. Liu, H.; Gu, L.-B.; Tu, Y.; Hu, H.; Huang, Y.-R.; Sun, W. Emodin ameliorates cisplatin-induced apoptosis of rat renal tubular cells in vitro by activating autophagy. Acta Pharmacol. Sin. 2016, 37, 235-245. [CrossRef]

97. Xing, J.; Hou, J.; Ma, Z.; Wang, Z.; Ren, S.; Wang, Y.; Liu, W.; Chen, C.; Li, W. Ginsenoside Rb3 provides protective effects against cisplatin-induced nephrotoxicity via regulation of AMPK-/mTOR-mediated autophagy and inhibition of apoptosis in vitro and in vivo. Cell Prolif. 2019, 52, e12627. [CrossRef] [PubMed]

98. Yang, H.; Gao, Y.; Fan, X.; Liu, X.; Peng, L.; Ci, X. Oridonin Sensitizes Cisplatin-Induced Apoptosis via AMPK/Akt/mTORDependent Autophagosome Accumulation in A549 Cells. Front. Oncol. 2019, 9, 769. [CrossRef]

99. Singh, M.P.; Chauhan, A.K.; Kang, S.C. Morin hydrate ameliorates cisplatin-induced ER stress, inflammation and autophagy in HEK-293 cells and mice kidney via PARP-1 regulation. Int. Immunopharmacol. 2018, 56, 156-167. [CrossRef]

100. Liu, S.; Hartleben, B.; Kretz, O.; Wiech, T.; Igarashi, P.; Mizushima, N.; Walz, G.; Huber, T.B. Autophagy plays a critical role in kidney tubule maintenance, aging and ischemia-reperfusion injury. Autophagy 2012, 8, 826-837. [CrossRef]

101. Takahashi, A.; Kimura, T.; Takabatake, Y.; Namba, T.; Kaimori, J.; Kitamura, H.; Matsui, I.; Niimura, F.; Matsusaka, T.; Fujita, N.; et al. Autophagy Guards Against Cisplatin-Induced Acute Kidney Injury. Am. J. Pathol. 2012, 180, 517-525. [CrossRef] [PubMed] 
102. Inoue, K.; Kuwana, H.; Shimamura, Y.; Ogata, K.; Taniguchi, Y.; Kagawa, T.; Horino, T.; Takao, T.; Morita, T.; Sasaki, S.; et al. Cisplatin-induced macroautophagy occurs prior to apoptosis in proximal tubules in vivo. Clin. Exp. Nephrol. 2009, 14, 112-122. [CrossRef]

103. Zhao, L.; Hu, C.; Zhang, P.; Jiang, H.; Chen, J. Mesenchymal stem cell therapy targeting mitochondrial dysfunction in acute kidney injury. J. Transl. Med. 2019, 17, 142. [CrossRef] [PubMed]

104. Zhao, C.; Chen, Z.; Xu, X.; An, X.; Duan, S.; Huang, Z.; Zhang, C.; Wu, L.; Zhang, B.; Zhang, A.; et al. Pink1/Parkin-mediated mitophagy play a protective role in cisplatin induced renal tubular epithelial cells injury. Exp. Cell Res. 2017, 350, 390-397. [CrossRef]

105. Zhou, L.; Zhang, L.; Zhang, Y.; Yu, X.; Sun, X.; Zhu, T.; Li, X.; Liang, W.; Han, Y.; Qin, C. PINK1 Deficiency Ameliorates Cisplatin-Induced Acute Kidney Injury in Rats. Front. Physiol. 2019, 10, 1225. [CrossRef] [PubMed]

106. Tang, C.; Han, H.; Liu, Z.; Liu, Y.; Yin, L.; Cai, J.; He, L.; Liu, Y.; Chen, G.; Zhang, Z.; et al. Activation of BNIP3-mediated mitophagy protects against renal ischemia-reperfusion injury. Cell Death Dis. 2019, 10, 1-15. [CrossRef] [PubMed]

107. Ishihara, M.; Urushido, M.; Hamada, K.; Matsumoto, T.; Shimamura, Y.; Ogata, K.; Inoue, K.; Taniguchi, Y.; Horino, T.; Fujieda, M.; et al. Sestrin-2 and BNIP3 regulate autophagy and mitophagy in renal tubular cells in acute kidney injury. Am. J. Physiol. Physiol. 2013, 305, F495-F509. [CrossRef] [PubMed]

108. Liang, X.; Yang, Y.; Huang, Z.; Zhou, J.; Li, Y.; Zhong, X. Panax notoginseng saponins mitigate cisplatin induced nephrotoxicity by inducing mitophagy via HIF-1 $\alpha$. Oncotarget 2017, 8, 102989-103003. [CrossRef]

109. Saxton, R.A.; Sabatini, D.M. mTOR Signaling in Growth, Metabolism, and Disease. Cell 2017, 169, 361-371. [CrossRef]

110. Wei, L.; Chen, W.; Zou, Y.; Huang, H.; Pan, B.; Jin, S.; Huang, R.; Nie, S.; Kong, G. AMP-activated protein kinase regulates autophagic protection against cisplatin-induced tissue injury in the kidney. Genet. Mol. Res. 2015, 14, 12006-12015. [CrossRef]

111. Yang, A.; Liu, F.; Guan, B.; Luo, Z.; Lin, J.; Fang, W.; Liu, L.; Zuo, W. p53 induces miR-199a-3p to suppress mechanistic target of rapamycin activation in cisplatin-induced acute kidney injury. J. Cell. Biochem. 2019, 120, 17625-17634. [CrossRef] [PubMed]

112. Zhang, D.; Pan, J.; Xiang, X.; Liu, Y.; Dong, G.; Livingston, M.J.; Chen, J.-K.; Yin, X.-M.; Dong, Z. Protein Kinase C $\delta$ Suppresses Autophagy to Induce Kidney Cell Apoptosis in Cisplatin Nephrotoxicity. J. Am. Soc. Nephrol. 2016, 28, 1131-1144. [CrossRef] [PubMed]

113. Dong, G.; Luo, J.; Kumar, V.; Dong, Z. Inhibitors of histone deacetylases suppress cisplatin-induced p53 activation and apoptosis in renal tubular cells. Am. J. Physiol. Physiol. 2010, 298, F293-F300. [CrossRef] [PubMed]

114. Liu, J.; Livingston, M.J.; Dong, G.; Tang, C.; Su, Y.; Wu, G.; Yin, X.-M.; Dong, Z. Histone deacetylase inhibitors protect against cisplatin-induced acute kidney injury by activating autophagy in proximal tubular cells. Cell Death Dis. 2018, 9, 1-15. [CrossRef]

115. Mehr, A.P.; Tran, M.; Ralto, K.M.; Leaf, D.; Washco, V.; Messmer, J.; Lerner, A.; Kher, A.; Kim, S.H.; Khoury, C.C.; et al. De novo NAD+ biosynthetic impairment in acute kidney injury in humans. Nat. Med. 2018, 24, 1351-1359. [CrossRef] [PubMed]

116. Guan, Y.; Wang, S.-R.; Huang, X.-Z.; Xie, Q.-H.; Xu, Y.-Y.; Shang, D.; Hao, C.-M. Nicotinamide Mononucleotide, an NAD+ Precursor, Rescues Age-Associated Susceptibility to AKI in a Sirtuin 1-Dependent Manner. J. Am. Soc. Nephrol. 2017, 28, 2337-2352. [CrossRef] [PubMed]

117. Morevati, M.; Egstrand, S.; Nordholm, A.; Mace, M.L.; Andersen, C.B.; Salmani, R.; Olgaard, K.; Lewin, E. Effect of NAD+ boosting on kidney ischemia-reperfusion injury. PLoS ONE 2021, 16, e0252554. [CrossRef]

118. Huang, R.; Xu, Y.; Wan, W.; Shou, X.; Qian, J.; You, Z.; Liu, B.; Chang, C.; Zhou, T.; Lippincott-Schwartz, J.; et al. Deacetylation of Nuclear LC3 Drives Autophagy Initiation under Starvation. Mol. Cell 2015, 57, 456-466. [CrossRef]

119. Lee, I.H.; Cao, L.; Mostoslavsky, R.; Lombard, D.; Liu, J.; Bruns, N.E.; Tsokos, M.; Alt, F.W.; Finkel, T. A role for the NADdependent deacetylase Sirt1 in the regulation of autophagy. Proc. Natl. Acad. Sci. USA 2008, 105, 3374-3379. [CrossRef] [PubMed]

120. Hariharan, N.; Maejima, Y.; Nakae, J.; Paik, J.; DePinho, R.; Sadoshima, J. Deacetylation of FoxO by Sirt1 Plays an Essential Role in Mediating Starvation-Induced Autophagy in Cardiac Myocytes. Circ. Res. 2010, 107, 1470-1482. [CrossRef] [PubMed]

121. Inoki, K.; Zhu, T.; Guan, K.-L. TSC2 Mediates Cellular Energy Response to Control Cell Growth and Survival. Cell 2003, 115, 577-590. [CrossRef]

122. Shaw, R.J.; Kosmatka, M.; Bardeesy, N.; Hurley, R.L.; Witters, L.A.; DePinho, R.; Cantley, L.C. The tumor suppressor LKB1 kinase directly activates AMP-activated kinase and regulates apoptosis in response to energy stress. Proc. Natl. Acad. Sci. USA 2004, 101, 3329-3335. [CrossRef]

123. Wei, Y.; Pattingre, S.; Sinha, S.; Bassik, M.; Levine, B. JNK1-Mediated Phosphorylation of Bcl-2 Regulates Starvation-Induced Autophagy. Mol. Cell 2008, 30, 678-688. [CrossRef]

124. Zalckvar, E.; Berissi, H.; Mizrachy, L.; Idelchuk, Y.; Koren, I.; Eisenstein, M.; Sabanay, H.; Pinkas-Kramarski, R.; Kimchi, A. DAP-kinase-mediated phosphorylation on the BH3 domain of beclin 1 promotes dissociation of beclin 1 from Bcl-XL and induction of autophagy. EMBO Rep. 2009, 10, 285-292. [CrossRef] [PubMed]

125. B'Chir, W.; Maurin, A.-C.; Carraro, V.; Averous, J.; Jousse, C.; Muranishi, Y.; Parry, L.; Stepien, G.; Fafournoux, P.; Bruhat, A. The eIF2 $\alpha$ /ATF4 pathway is essential for stress-induced autophagy gene expression. Nucleic Acids Res. 2013, 41, 7683-7699. [CrossRef] [PubMed]

126. Criollo, A.; Senovilla, L.; Authier, H.; Maiuri, M.C.; Morselli, E.; Vitale, I.; Kepp, O.; Tasdemir, E.; Galluzzi, L.; Shen, S.; et al. The IKK complex contributes to the induction of autophagy. EMBO J. 2009, 29, 619-631. [CrossRef] 
127. Settembre, C.; Di Malta, C.; Polito, V.A.; Garcia-Arencibia, M.; Vetrini, F.; Erdin, S.; Huynh, T.; Medina, D.L.; Colella, P.; Sardiello, M.; et al. TFEB Links Autophagy to Lysosomal Biogenesis. Science 2011, 332, 1429-1433. [CrossRef]

128. Chauhan, S.; Goodwin, J.G.; Chauhan, S.; Manyam, G.; Wang, J.; Kamat, A.M.; Boyd, D.D. ZKSCAN3 Is a Master Transcriptional Repressor of Autophagy. Mol. Cell 2013, 50,16-28. [CrossRef]

129. Zhu, L.; Yuan, Y.; Yuan, L.; Li, L.; Liu, F.; Liu, J.; Chen, Y.; Lu, Y.; Cheng, J. Activation of TFEB-mediated autophagy by trehalose attenuates mitochondrial dysfunction in cisplatin-induced acute kidney injury. Theranostics 2020, 10, 5829-5844. [CrossRef] [PubMed]

130. Venkatachalam, M.A.; Weinberg, J.M.; Kriz, W.; Bidani, A.K. Failed Tubule Recovery, AKI-CKD Transition, and Kidney Disease Progression. J. Am. Soc. Nephrol. 2015, 26, 1765-1776. [CrossRef] [PubMed]

131. Basile, D.P.; Bonventre, J.V.; Mehta, R.L.; Nangaku, M.; Unwin, R.; Rosner, M.H.; Kellum, J.A.; Ronco, C. Progression after AKI: Understanding Maladaptive Repair Processes to Predict and Identify Therapeutic Treatments. J. Am. Soc. Nephrol. 2015, 27, 687-697. [CrossRef]

132. Liu, B.-C.; Tang, T.-T.; Lv, L.-L.; Lan, H.-Y. Renal tubule injury: A driving force toward chronic kidney disease. Kidney Int. 2018, 93, 568-579. [CrossRef] [PubMed]

133. Ferenbach, D.; Bonventre, J.V. Mechanisms of maladaptive repair after AKI leading to accelerated kidney ageing and CKD. Nat. Rev. Nephrol. 2015, 11, 264-276. [CrossRef] [PubMed]

134. Liu, Y. Cellular and molecular mechanisms of renal fibrosis. Nat. Rev. Nephrol. 2011, 7, 684-696. [CrossRef] [PubMed]

135. He, L.; Livingston, M.J.; Dong, Z. Autophagy in Acute Kidney Injury and Repair. Nephron 2014, 127, 56-60. [CrossRef]

136. Yang, L.; Besschetnova, T.Y.; Brooks, C.R.; Shah, J.V.; Bonventre, J.V. Epithelial cell cycle arrest in G2/M mediates kidney fibrosis after injury. Nat. Med. 2010, 16, 535-543. [CrossRef]

137. Bao, J.; Shi, Y.; Tao, M.; Liu, N.; Zhuang, S.; Yuan, W. Pharmacological inhibition of autophagy by 3-MA attenuates hyperuricemic nephropathy. Clin. Sci. 2018, 132, 2299-2322. [CrossRef]

138. Canaud, G.; Brooks, C.R.; Kishi, S.; Taguchi, K.; Nishimura, K.; Magassa, S.; Scott, A.; Hsiao, L.-L.; Ichimura, T.; Terzi, F.; et al. Cyclin G1 and TASCC regulate kidney epithelial cell $\mathrm{G}_{2}-\mathrm{M}$ arrest and fibrotic maladaptive repair. Sci. Transl. Med. 2019, 11, eaav4754. [CrossRef]

139. Choi, M.E. Autophagy in Kidney Disease. Annu. Rev. Physiol. 2020, 82, 297-322. [CrossRef]

140. Li, L.; Zepeda-Orozco, D.; Black, R.; Lin, F. Autophagy Is a Component of Epithelial Cell Fate in Obstructive Uropathy. Am. J. Pathol. 2010, 176, 1767-1778. [CrossRef]

141. Zehender, A.; Li, Y.-N.; Lin, N.-Y.; Stefanica, A.; Nüchel, J.; Chen, C.-W.; Hsu, H.-H.; Zhu, H.; Ding, X.; Huang, J.; et al. TGF $\beta$ promotes fibrosis by MYST1-dependent epigenetic regulation of autophagy. Nat. Commun. 2021, 12, 1-19. [CrossRef] [PubMed]

142. Kim, Y.-A.; Kim, H.-J.; Gwon, M.-G.; Gu, H.; An, H.-J.; Bae, S.; Leem, J.; Jung, H.; Park, K.-K. Inhibitory Effects of STAT3 Transcription Factor by Synthetic Decoy ODNs on Autophagy in Renal Fibrosis. Biomedicines 2021, 9, 331. [CrossRef]

143. Shi, Y.; Tao, M.; Ma, X.; Hu, Y.; Huang, G.; Qiu, A.; Zhuang, S.; Liu, N. Delayed treatment with an autophagy inhibitor 3-MA alleviates the progression of hyperuricemic nephropathy. Cell Death Dis. 2020, 11, 1-16. [CrossRef] [PubMed]

144. Kim, S.I.; Na, H.-J.; Ding, Y.; Wang, Z.; Lee, S.-J.; Choi, M.E. Autophagy Promotes Intracellular Degradation of Type I Collagen Induced by Transforming Growth Factor (TGF)- $\beta$. J. Biol. Chem. 2012, 287, 11677-11688. [CrossRef] [PubMed]

145. Xu, G.; Yue, F.; Huang, H.; He, Y.; Li, X.; Zhao, H.; Su, Z.; Jiang, X.; Li, W.; Zou, J.; et al. Defects in MAP1S-mediated autophagy turnover of fibronectin cause renal fibrosis. Aging 2016, 8, 977-985. [CrossRef] [PubMed]

146. Kim, W.-Y.; Nam, S.A.; Song, H.C.; Ko, J.S.; Park, S.H.; Kim, H.L.; Choi, E.J.; Kim, Y.-S.; Kim, J. The role of autophagy in unilateral ureteral obstruction rat model. Nephrology 2011, 17, 148-159. [CrossRef]

147. Brooks, C.R.; Yeung, M.Y.; Brooks, Y.S.; Chen, H.; Ichimura, T.; Henderson, J.M.; Bonventre, J.V. KIM-1-/TIM-1-mediated phagocytosis links ATG 5-/ ULK 1-dependent clearance of apoptotic cells to antigen presentation. EMBO J. 2015, 34, $2441-2464$. [CrossRef]

148. Lin, Q.; Li, S.; Jiang, N.; Jin, H.; Shao, X.; Zhu, X.; Wu, J.; Zhang, M.; Zhang, Z.; Shen, J.; et al. Inhibiting NLRP3 inflammasome attenuates apoptosis in contrast-induced acute kidney injury through the upregulation of HIF1A and BNIP3-mediated mitophagy. Autophagy 2020, 17, 2975-2990. [CrossRef]

149. Kim, S.-M.; Kim, Y.G.; Kim, D.-J.; Park, S.H.; Jeong, K.-H.; Lee, Y.H.; Lim, S.J.; Lee, S.-H.; Moon, J.-Y. Inflammasome-Independent Role of NLRP3 Mediates Mitochondrial Regulation in Renal Injury. Front. Immunol. 2018, 9, 2563. [CrossRef]

150. Xu, Y.; Wang, J.; Xu, W.; Ding, F.; Ding, W. Prohibitin 2-mediated mitophagy attenuates renal tubular epithelial cells injury by regulating mitochondrial dysfunction and NLRP3 inflammasome activation. Am. J. Physiol. Physiol. 2019, 316, F396-F407. [CrossRef]

151. Peng, X.; Wang, Y.; Li, H.; Fan, J.; Shen, J.; Yu, X.; Zhou, Y.; Mao, H. ATG5-mediated autophagy suppresses NF-kB signaling to limit epithelial inflammatory response to kidney injury. Cell Death Dis. 2019, 10, 1-16. [CrossRef]

152. Andrianova, N.V.; Zorova, L.D.; Babenko, V.A.; Pevzner, I.B.; Popkov, V.A.; Silachev, D.N.; Plotnikov, E.Y.; Zorov, D.B. Rapamycin Is Not Protective against Ischemic and Cisplatin-Induced Kidney Injury. Biochemistry (Moscow) 2019, 84, 1502-1512. [CrossRef] [PubMed]

153. Nakagawa, S.; Nishihara, K.; Inui, K.-I.; Masuda, S. Involvement of autophagy in the pharmacological effects of the mTOR inhibitor everolimus in acute kidney injury. Eur. J. Pharmacol. 2012, 696, 143-154. [CrossRef] [PubMed] 
154. Zucali, P.A.; De Pas, T.; Palmieri, G.; Favaretto, A.; Chella, A.; Tiseo, M.; Caruso, M.; Simonelli, M.; Perrino, M.; De Vincenzo, F.; et al. Phase II Study of Everolimus in Patients With Thymoma and Thymic Carcinoma Previously Treated With Cisplatin-Based Chemotherapy. J. Clin. Oncol. 2018, 36, 342-349. [CrossRef] [PubMed]

155. Mosley, J.; Poirier, J.; Seachrist, D.D.; Landis, M.D.; Keri, R.A. Rapamycin inhibits multiple stages of c-Neu/ErbB2-induced tumor progression in a transgenic mouse model of HER2-positive breast cancer. Mol. Cancer Ther. 2007, 6, 2188-2197. [CrossRef]

156. Mabuchi, S.; Altomare, D.A.; Connolly, D.C.; Klein-Szanto, A.; Litwin, S.; Hoelzle, M.K.; Hensley, H.H.; Hamilton, T.C.; Testa, J.R. RAD001 (Everolimus) Delays Tumor Onset and Progression in a Transgenic Mouse Model of Ovarian Cancer. Cancer Res. 2007, 67, 2408-2413. [CrossRef]

157. Li, J.; Gui, Y.; Ren, J.; Liu, X.; Feng, Y.; Zeng, Z.; He, W.; Yang, J.; Dai, C. Metformin Protects Against Cisplatin-Induced Tubular Cell Apoptosis and Acute Kidney Injury via AMPK $\alpha$-regulated Autophagy Induction. Sci. Rep. 2016, 6, 23975. [CrossRef]

158. Ben Sahra, I.; Le Marchand-Brustel, Y.; Tanti, J.-F.; Bost, F. Metformin in Cancer Therapy: A New Perspective for an Old Antidiabetic Drug? Mol. Cancer Ther. 2010, 9, 1092-1099. [CrossRef]

159. Guo, L.; Cui, J.; Wang, H.; Medina, R.; Zhang, S.; Zhang, X.; Zhuang, Z.; Lin, Y. Metformin enhances anti-cancer effects of cisplatin in meningioma through AMPK-mTOR signaling pathways. Mol. Ther. Oncol. 2021, 20, 119-131. [CrossRef]

160. Lambert, I.H.; Nielsen, D.; Stürup, S. Impact of the histone deacetylase inhibitor trichostatin A on active uptake, volume-sensitive release of taurine, and cell fate in human ovarian cancer cells. Am. J. Physiol. Physiol. 2020, 318, C581-C597. [CrossRef]

161. Tang, J.; Shi, Y.; Liu, N.; Xu, L.; Zang, X.; Li, P.; Zhang, J.; Zheng, X.; Qiu, A.; Zhuang, S. Blockade of histone deacetylase 6 protects against cisplatin-induced acute kidney injury. Clin. Sci. 2018, 132, 339-359. [CrossRef] [PubMed]

162. Wang, L.; Xiang, S.; Williams, K.A.; Dong, H.; Bai, W.; Nicosia, S.V.; Khochbin, S.; Bepler, G.; Zhang, X. Depletion of HDAC6 Enhances Cisplatin-Induced DNA Damage and Apoptosis in Non-Small Cell Lung Cancer Cells. PLoS ONE 2012, 7, e44265. [CrossRef]

163. Selvi, S.K.; Vinoth, A.; Varadharajan, T.; Weng, C.F.; Padma, V.V. Neferine augments therapeutic efficacy of cisplatin through ROSmediated non-canonical autophagy in human lung adenocarcinoma (A549 cells). Food Chem. Toxicol. 2017, 103, 28-40. [CrossRef] [PubMed]

164. Li, X.; Wang, H.; Wang, J.; Chen, Y.; Yin, X.; Shi, G.; Li, H.; Hu, Z.; Liang, X. Emodin enhances cisplatin-induced cytotoxicity in human bladder cancer cells through ROS elevation and MRP1 downregulation. BMC Cancer 2016, 16, 1-10. [CrossRef]

165. Ko, J.-C.; Su, Y.-J.; Lin, S.-T.; Jhan, J.-Y.; Ciou, S.-C.; Cheng, C.-M.; Chiu, Y.-F.; Kuo, Y.-H.; Tsai, M.-S.; Lin, Y.-W. Emodin enhances cisplatin-induced cytotoxicity via down-regulation of ERCC1 and inactivation of ERK1/2. Lung Cancer 2010, 69, 155-164. [CrossRef]

166. Lee, D.; Bin Kang, K.; Kim, H.W.; Park, J.S.; Hwang, G.S.; Kang, K.S.; Choi, S.; Yamabe, N.; Kim, K.H. Unique Triterpenoid of Jujube Root Protects Cisplatin-induced Damage in Kidney Epithelial LLC-PK1 Cells via Autophagy Regulation. Nutrients 2020, 12, 677. [CrossRef] [PubMed]

167. Sun, C.-Y.; Nie, J.; Zheng, Z.-L.; Zhao, J.; Wu, L.-M.; Zhu, Y.; Su, Z.-Q.; Zheng, G.-J.; Feng, B. Renoprotective effect of scutellarin on cisplatin-induced renal injury in mice: Impact on inflammation, apoptosis, and autophagy. Biomed. Pharmacother. 2019, 112, 108647. [CrossRef]

168. Sun, C.-Y.; Zhu, Y.; Li, X.-F.; Wang, X.-Q.; Tang, L.-P.; Su, Z.-Q.; Li, C.-Y.; Zheng, G.-J.; Feng, B. Scutellarin Increases CisplatinInduced Apoptosis and Autophagy to Overcome Cisplatin Resistance in Non-small Cell Lung Cancer via ERK/p53 and c-met/AKT Signaling Pathways. Front. Pharmacol. 2018, 9, 92. [CrossRef]

169. Del Bello, B.; Toscano, M.; Moretti, D.; Maellaro, E. Cisplatin-Induced Apoptosis Inhibits Autophagy, Which Acts as a Pro-Survival Mechanism in Human Melanoma Cells. PLoS ONE 2013, 8, e57236. [CrossRef]

170. Michaud, M.; Martins, I.; Sukkurwala, A.Q.; Adjemian, S.; Ma, Y.; Pellegatti, P.; Shen, S.; Kepp, O.; Scoazec, M.; Mignot, G.; et al. Autophagy-Dependent Anticancer Immune Responses Induced by Chemotherapeutic Agents in Mice. Science 2011, 334, 1573-1577. [CrossRef]

171. Potočnjak, I.; Šimić, L.; Vukelić, I.; Domitrović, R. Oleanolic acid attenuates cisplatin-induced nephrotoxicity in mice and chemosensitizes human cervical cancer cells to cisplatin cytotoxicity. Food Chem. Toxicol. 2019, 132, 110676. [CrossRef]

172. Checkley, L.A.; Rho, O.; Moore, T.; Hursting, S.; DiGiovanni, J. Rapamycin Is a Potent Inhibitor of Skin Tumor Promotion by 12-O-Tetradecanoylphorbol-13-Acetate. Cancer Prev. Res. 2011, 4, 1011-1020. [CrossRef] [PubMed]

173. Shi, Y.; Song, Q.; Hu, D.; Zhuang, X.; Yu, S.; Teng, D. Oleanolic acid induced autophagic cell death in hepatocellular carcinoma cells via PI3K/Akt/mTOR and ROS-dependent pathway. Korean J. Physiol. Pharmacol. 2016, 20, 237-243. [CrossRef] [PubMed]

174. Bao, L.; Jaramillo, M.C.; Zhang, Z.; Zheng, Y.; Yao, M.; Zhang, N.D.; Yi, X. Induction of autophagy contributes to cisplatin resistance in human ovarian cancer cells. Mol. Med. Rep. 2014, 11, 91-98. [CrossRef]

175. Lin, W.; Li, Z. Blockage of cisplatin-induced autophagy sensitizes cervical cancer cells to cisplatin. Genet. Mol. Res. 2015, 14, 16905-16912. [CrossRef]

176. Zhang, M.; Hagan, C.T.; Min, Y.; Foley, H.; Tian, X.; Yang, F.; Mi, Y.; Au, K.M.; Medik, Y.; Roche, K.; et al. Nanoparticle co-delivery of wortmannin and cisplatin synergistically enhances chemoradiotherapy and reverses platinum resistance in ovarian cancer models. Biomaterials 2018, 169, 1-10. [CrossRef] [PubMed]

177. Bar, J.; Lukaschuk, N.; Zalcenstein, A.; Wilder, S.; Seger, R.; Oren, M. The PI3K inhibitor LY294002 prevents p53 induction by DNA damage and attenuates chemotherapy-induced apoptosis. Cell Death Differ. 2005, 12, 1578-1587. [CrossRef] 
178. Lin, J.-F.; Lin, Y.-C.; Tsai, T.-F.; Chen, H.-E.; Chou, K.-Y.; Hwang, T.I.-S. Cisplatin induces protective autophagy through activation of BECN1 in human bladder cancer cells. Drug Des. Dev. Ther. 2017, 11, 1517-1533. [CrossRef]

179. Aga, T.; Endo, K.; Tsuji, A.; Aga, M.; Moriyama-Kita, M.; Ueno, T.; Nakanishi, Y.; Hatano, M.; Kondo, S.; Sugimoto, H.; et al. Inhibition of autophagy by chloroquine makes chemotherapy in nasopharyngeal carcinoma more efficient. Auris Nasus Larynx 2018, 46, 443-450. [CrossRef]

180. Su, Z.; Li, G.; Liu, C.; Ren, S.; Deng, T.; Zhang, S.; Tian, Y.; Liu, Y.; Qiu, Y. Autophagy inhibition impairs the epithelial-mesenchymal transition and enhances cisplatin sensitivity in nasopharyngeal carcinoma. Oncol. Lett. 2017, 13, 4147-4154. [CrossRef]

181. Zhang, H.-Q.; Fang, N.; Liu, X.-M.; Xiong, S.-P.; Liao, Y.-Q.; Jin, W.-J.; Song, R.-F.; Wan, Y.-Y. Antitumor Activity of Chloroquine in Combination with Cisplatin in Human Gastric Cancer Xenografts. Asian Pac. J. Cancer Prev. 2015, 16, 3907-3912. [CrossRef]

182. Fukuda, T.; Oda, K.; Wada-Hiraike, O.; Sone, K.; Inaba, K.; Ikeda, Y.; Miyasaka, A.; Kashiyama, T.; Tanikawa, M.; Arimoto, T.; et al. The anti-malarial chloroquine suppresses proliferation and overcomes cisplatin resistance of endometrial cancer cells via autophagy inhibition. Gynecol. Oncol. 2015, 137, 538-545. [CrossRef]

183. Shen, C.; Wang, W.; Tao, L.; Liu, B.; Yang, Z.; Tao, H. Chloroquine blocks the autophagic process in cisplatin-resistant osteosarcoma cells by regulating the expression of p62/SQSTM1. Int. J. Mol. Med. 2013, 32, 448-456. [CrossRef] [PubMed]

184. Kimura, T.; Takabatake, Y.; Takahashi, A.; Isaka, Y. Chloroquine in Cancer Therapy: A Double-Edged Sword of Autophagy. Cancer Res. 2013, 73, 3-7. [CrossRef]

185. Guo, J.Y.; Xia, B.; White, E. Autophagy-Mediated Tumor Promotion. Cell 2013, 155, 1216-1219. [CrossRef] [PubMed]

186. Singh, M.P.; Cho, H.J.; Kim, J.T.; Baek, K.E.; Lee, H.G.; Kang, S.C. Morin Hydrate Reverses Cisplatin Resistance by Impairing PARP1/HMGB1-Dependent Autophagy in Hepatocellular Carcinoma. Cancers 2019, 11, 986. [CrossRef] [PubMed]

187. Chen, H.-Y.; White, E. Role of Autophagy in Cancer Prevention. Cancer Prev. Res. 2011, 4, 973-983. [CrossRef]

188. Degenhardt, K.; Mathew, R.; Beaudoin, B.; Bray, K.; Anderson, D.; Chen, G.; Mukherjee, C.; Shi, Y.; Gélinas, C.; Fan, Y.; et al. Autophagy promotes tumor cell survival and restricts necrosis, inflammation, and tumorigenesis. Cancer Cell 2006, 10, 51-64. [CrossRef] [PubMed]

189. Kim, M.; Jung, J.-Y.; Choi, S.; Lee, H.; Morales, L.D.; Koh, J.-T.; Kim, S.H.; Choi, Y.-D.; Choi, C.; Slaga, T.J.; et al. GFRA1 promotes cisplatin-induced chemoresistance in osteosarcoma by inducing autophagy. Autophagy 2016, 13, 149-168. [CrossRef] [PubMed] 